\title{
LEVEL II SCOUR ANALYSIS FOR BRIDGE 6 (GLOVTH00030006) on TOWN HIGHWAY 3, crossing the BARTON RIVER, GLOVER, VERMONT
}

Open-File Report 98-552

Prepared in cooperation with

VERMONT AGENCY OF TRANSPORTATION

and

FEDERAL HIGHWAY ADMINISTRATION

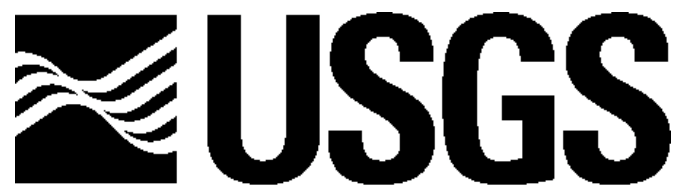

science for a changing world

U.S. Department of the Interior

U.S. Geological Survey 


\section{LEVEL II SCOUR ANALYSIS FOR BRIDGE 6 (GLOVTH00030006) on TOWN HIGHWAY 3, crossing the BARTON RIVER, \\ GLOVER, VERMONT \\ By SCOTT A. OLSON}

U.S. Geological Survey

Open-File Report 98-552

Prepared in cooperation with

VERMONT AGENCY OF TRANSPORTATION

and

FEDERAL HIGHWAY ADMINISTRATION 


\title{
U.S. DEPARTMENT OF THE INTERIOR BRUCE BABBITT, Secretary
}

\author{
U.S. GEOLOGICAL SURVEY
}

Thomas J. Casadevall, Acting Director

For additional information write to:

District Chief

U.S. Geological Survey 361 Commerce Way

Pembroke, NH 03275-3718
Copies of this report may be purchased from:

U.S. Geological Survey

Branch of Information Services

Open-File Reports Unit

Box 25286

Denver, CO 80225-0286 


\section{CONTENTS}

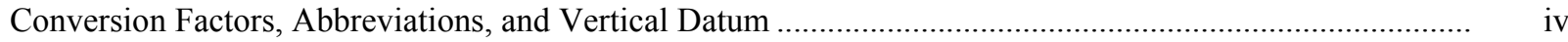

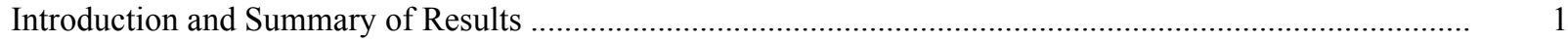

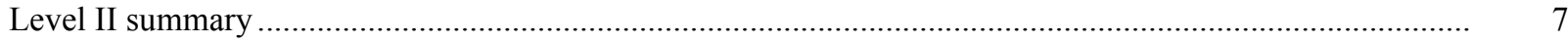

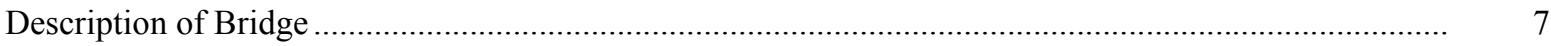

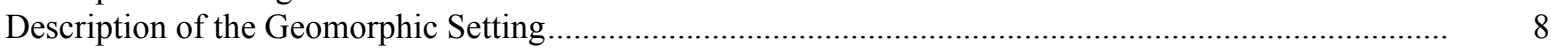

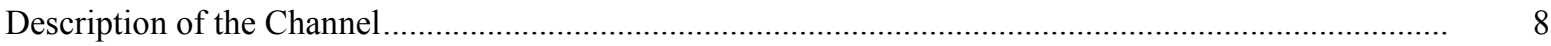

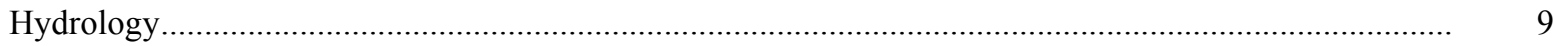

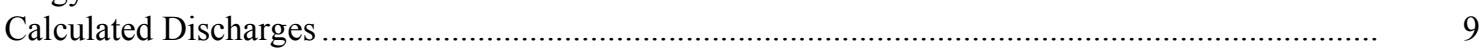

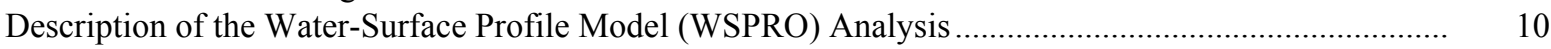

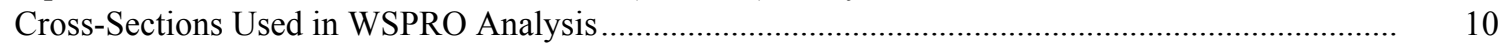

Data and Assumptions Used in WSPRO Model ........................................................................ 11

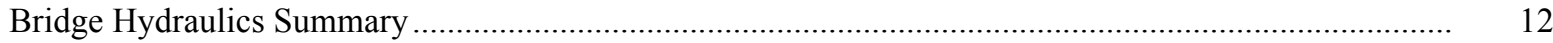

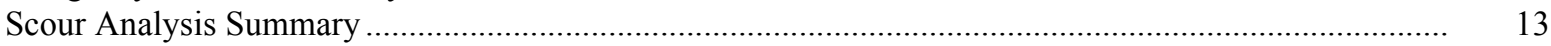

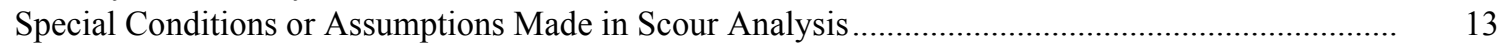

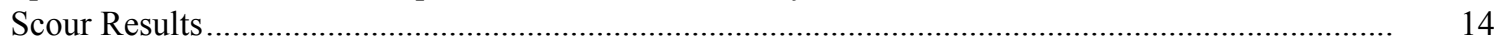

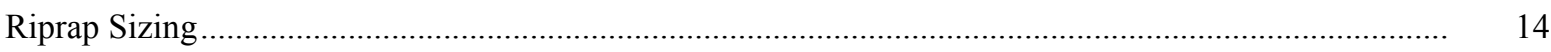

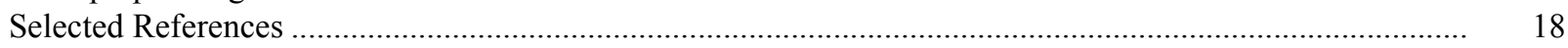

Appendices:

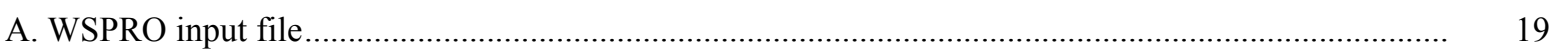

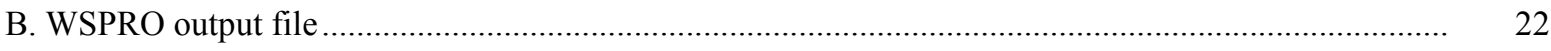

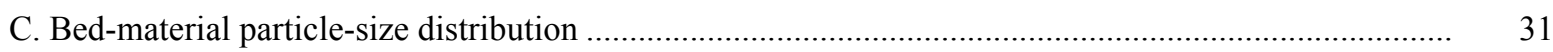

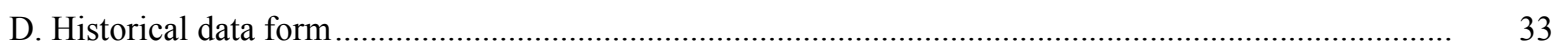

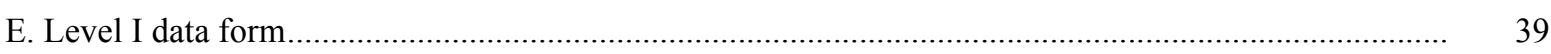

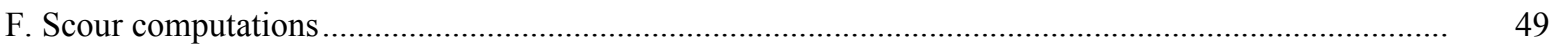

\section{FIGURES}

1. Map showing location of study area on USGS 1:24,000 scale map

2. Map showing location of study area on Vermont Agency of Transportation town highway map .....

3. Structure GLOVTH00030006 viewed from upstream (October 26, 1994).

4. Downstream channel viewed from structure GLOVTH00030006 (October 26, 1994).......................... 5

5. Upstream channel viewed from structure GLOVTH00030006 (October 26, 1994)................................ 6

6. Structure GLOVTH00030006 viewed from downstream (October 25, 1994).

7. Water-surface profiles for the 100- and 500-year discharges at structure

GLOVTH00030006 on Town Highway 3, crossing the Barton River,

Glover, Vermont......

8. Scour elevations for the 100- and 500-year discharges at structure

GLOVTH00030006 on Town Highway 3, crossing the Barton River,

Glover, Vermont.

\section{TABLES}

1. Remaining footing/pile depth at abutments for the 100-year discharge at structure

GLOVTH00030006 on Town Highway 3, crossing the Barton River,

Glover, Vermont

2. Remaining footing/pile depth at abutments for the 500-year discharge at structure

GLOVTH00030006 on Town Highway 3, crossing the Barton River,

Glover, Vermont 


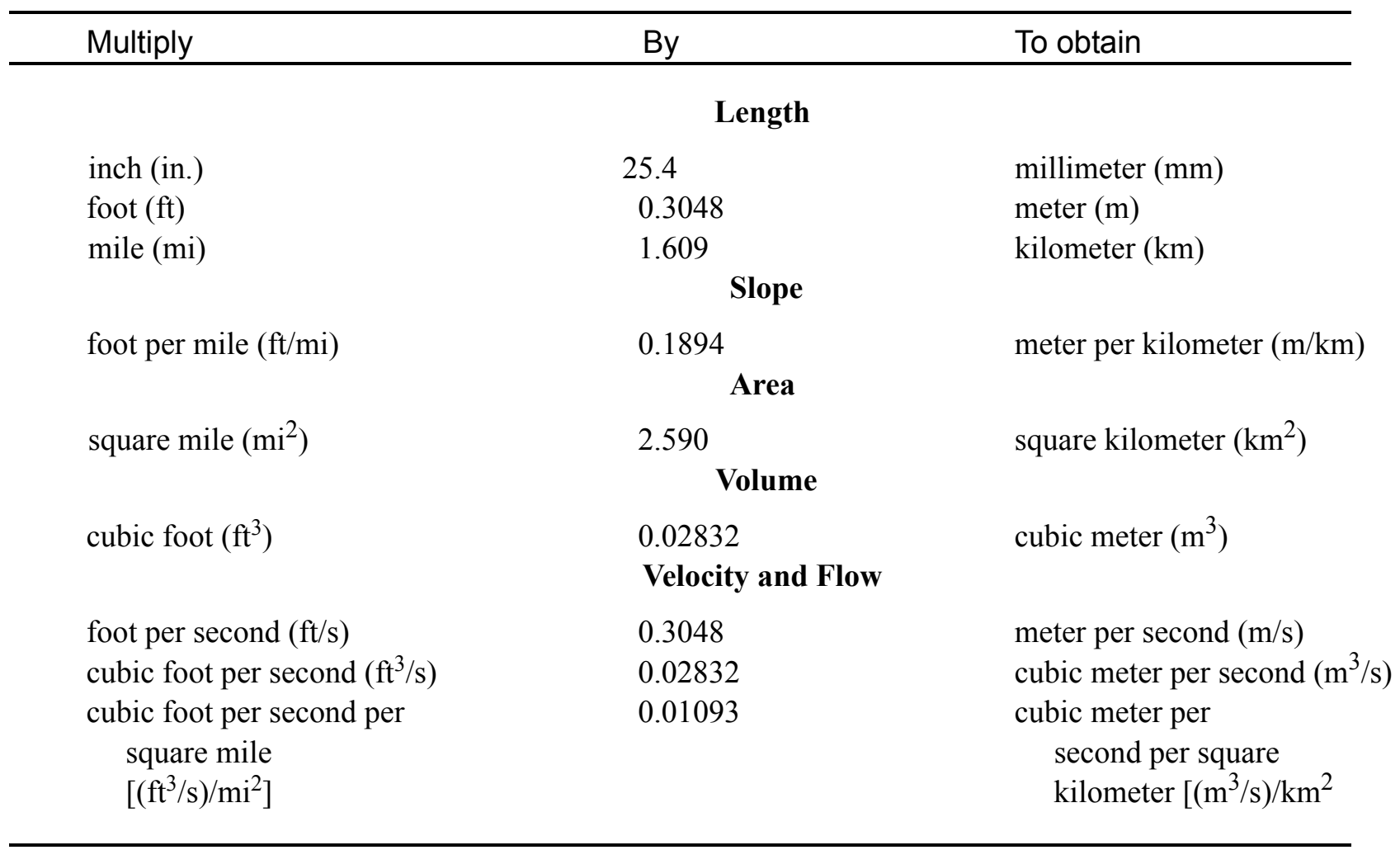

\section{OTHER ABBREVIATIONS}

$\begin{array}{lrlr}\mathrm{BF} & \text { bank full } & \text { LWW } & \text { left wingwall } \\ \mathrm{cfs} & \text { cubic feet per second } & \text { Max } & \text { maximum } \\ \mathrm{D}_{50} & \text { median diameter of bed material } & \text { MC } & \text { main channel } \\ \mathrm{DS} & \text { downstream } & \text { RAB } & \text { right abutment } \\ \mathrm{elev} & \text { elevation } & \text { RABUT } & \text { face of right abutment } \\ \mathrm{f} / \mathrm{p} & \text { flood plain } & \text { RB } & \text { right bank } \\ \mathrm{ft} & \text { square feet } & \text { ROB } & \text { right overbank } \\ \mathrm{ft} / \mathrm{ft} & \text { feet per foot } & \text { RWW } & \text { right wingwall } \\ \mathrm{FEMA} & \text { Federal Emergency Management Agency } & \text { TH } & \text { town highway } \\ \mathrm{FHWA} & \text { Federal Highway Administration } & \text { UB } & \text { under bridge } \\ \mathrm{JCT} & \text { junction } & \text { US } & \text { upstream } \\ \text { LAB } & \text { left abutment } & \text { USGS } & \text { United States Geological Survey } \\ \text { LABUT } & \text { face of left abutment } & \text { VTAOT } & \text { Vermont Agency of Transportation } \\ \text { LB } & \text { left bank } & \text { WSPRO } & \text { water-surface profile model } \\ \text { LOB } & \text { left overbank } & \text { yr } & \text { year }\end{array}$

In this report, the words "right" and "left" refer to directions that would be reported by an observer facing downstream. Sea level: In this report, "sea level" refers to the National Geodetic Vertical Datum of 1929-- a geodetic datum derived from a general adjustment of the first-order level nets of the United States and Canada, formerly called Sea Level Datum of 1929.

In the appendices, the above abbreviations may be combined. For example, USLB would represent upstream left bank. 


\title{
LEVEL II SCOUR ANALYSIS FOR BRIDGE 6 (GLOVTH00030006) ON TOWN HIGHWAY 3, CROSSING THE BARTON RIVER, GLOVER, VERMONT
}

\author{
By Scott A. Olson
}

\section{INTRODUCTION AND SUMMARY OF RESULTS}

This report provides the results of a detailed Level II analysis of scour potential at structure GLOVTH00030006 on Town Highway 3 crossing the Barton River, Glover, Vermont (figures 1-8). A Level II study is a basic engineering analysis of the site, including a quantitative analysis of stream stability and scour (FHWA, 1993). Results of a Level I scour investigation also are included in appendix $\mathrm{E}$ of this report. A Level I investigation provides a qualitative geomorphic characterization of the study site. Information on the bridge, gleaned from Vermont Agency of Transportation (VTAOT) files, was compiled prior to conducting Level I and Level II analyses and is found in appendix D.

The site is in the New England Upland section of the New England physiographic province in northern Vermont. The $19.0-\mathrm{mi}^{2}$ drainage area is in a predominantly rural and forested basin. In the vicinity of the study site, the surface cover is primarily lawns with homes and a few trees.

In the study area, the Barton River has a straight, constructed channel with a slope of approximately $0.01 \mathrm{ft} / \mathrm{ft}$, an average channel top width of $39 \mathrm{ft}$ and an average bank height of $6 \mathrm{ft}$. The channel bed material ranges from gravel to boulder with a median grain size $\left(\mathrm{D}_{50}\right)$ of $48.7 \mathrm{~mm}(0.160 \mathrm{ft})$. The geomorphic assessment at the time of the Level I and Level II site visit on October 25 and 26, 1994, indicated that the reach was constructed.

The Town Highway 3 crossing of the Barton River is a 41-ft-long, two-lane bridge consisting of one 37-foot concrete span (Vermont Agency of Transportation, written communication, August 4, 1994). The opening length of the structure parallel to the bridge face is $35 \mathrm{ft}$. The bridge is supported by vertical, concrete abutments with wingwalls. The channel is skewed approximately 30 degrees to the opening while the opening-skew-toroadway is 45 degrees. 
Scour $2.0 \mathrm{ft}$ deeper than the mean thalweg depth was observed along the left abutment during the Level I assessment. Scour countermeasures at the site include masonry walls along both banks upstream of the bridge, type- 2 stone fill (less than 36 inches diameter) along the upstream right wingwall and downstream right bank, type-3 stone fill (less than 48 inches diameter) along the upstream left wingwall and both downstream wingwalls, and type-4 stone fill (less than 60 inches diameter) along the downstream left bank. Additional details describing conditions at the site are included in the Level II Summary and appendices D

and $\mathrm{E}$.

Scour depths and recommended rock rip-rap sizes were computed using the general guidelines described in Hydraulic Engineering Circular 18 (Richardson and Davis, 1995) for the 100- and 500-year discharges. In addition, the incipient roadway-overtopping discharge was determined and analyzed as a potential worst-case scour scenario. Total scour at a highway crossing is comprised of three components: 1) long-term streambed degradation; 2) contraction scour (due to accelerated flow caused by a reduction in flow area at a bridge) and; 3) local scour (caused by accelerated flow around piers and abutments). Total scour is the sum of the three components. Equations are available to compute depths for contraction and local scour and a summary of the results of these computations follows.

Contraction scour for all modelled flows ranged from 0.1 to $0.9 \mathrm{ft}$. The worst-case contraction scour occurred at the 100-year discharge. Abutment scour ranged from 3.0 to $5.2 \mathrm{ft}$ at the left abutment with the worst case scour occurring at the 500-year discharge. Abutment scour ranged from 10.3 to 11.3 at the right abutment with the worst case scour occurring at the incipient roadway-overtopping discharge. Additional information on scour depths and depths to armoring are included in the section titled "Scour Results." Scouredstreambed elevations, based on the calculated scour depths, are presented in tables 1 and 2. A cross-section of the scour computed at the bridge is presented in figure 8. Scour depths were calculated assuming an infinite depth of erosive material and a homogeneous particlesize distribution.

Usually, computed scour depths are evaluated in combination with other information including (but not limited to) historical performance during flood events, the geomorphic stability assessment, existing scour protection measures, and the results of the hydraulic analyses. Therefore, scour depths adopted by VTAOT may differ from the computed values documented herein. 


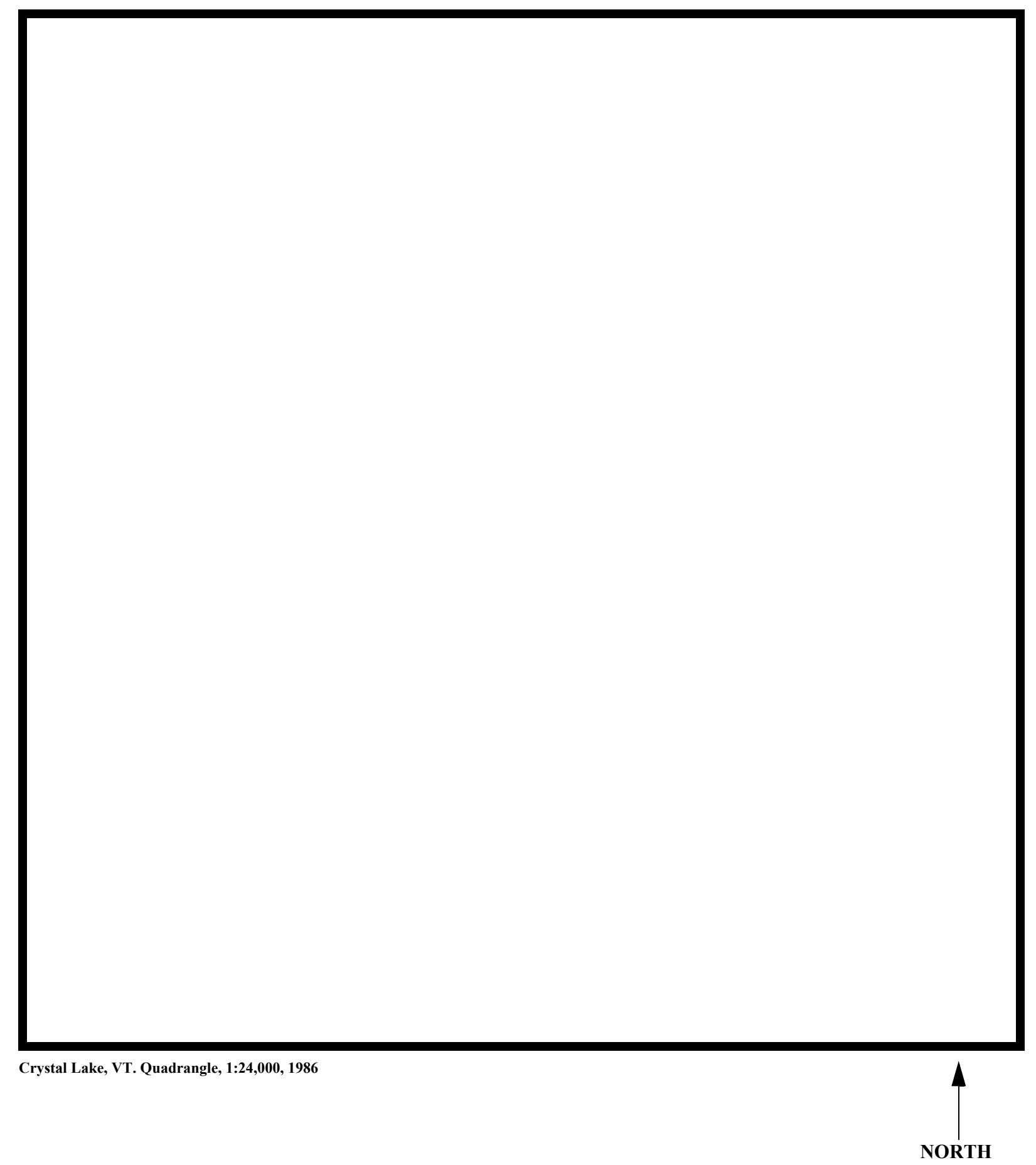

Figure 1. Location of study area on USGS 1:24,000 scale map. 
Figure 2. Location of study area on Vermont Agency of Transportation town highway map. 

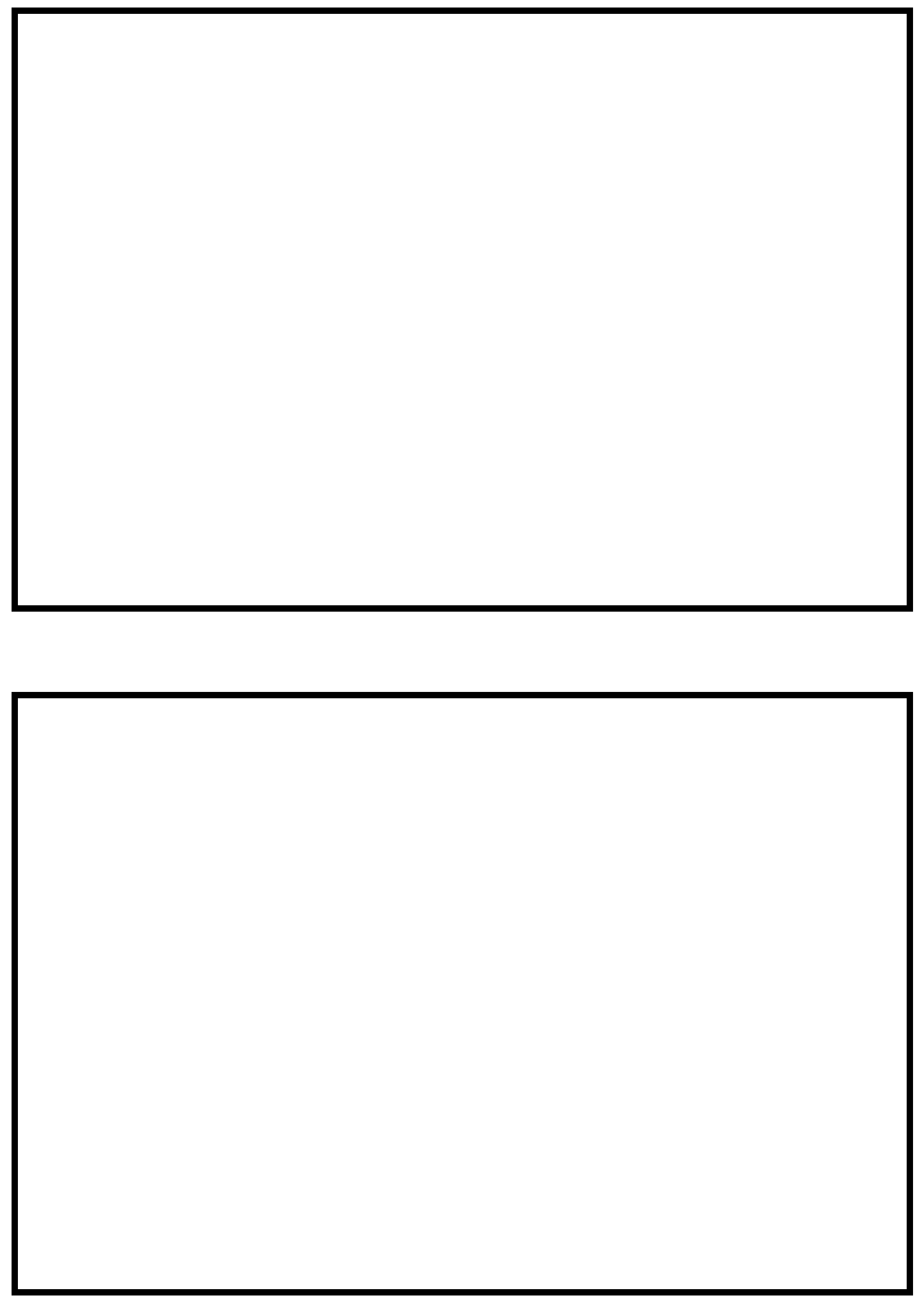

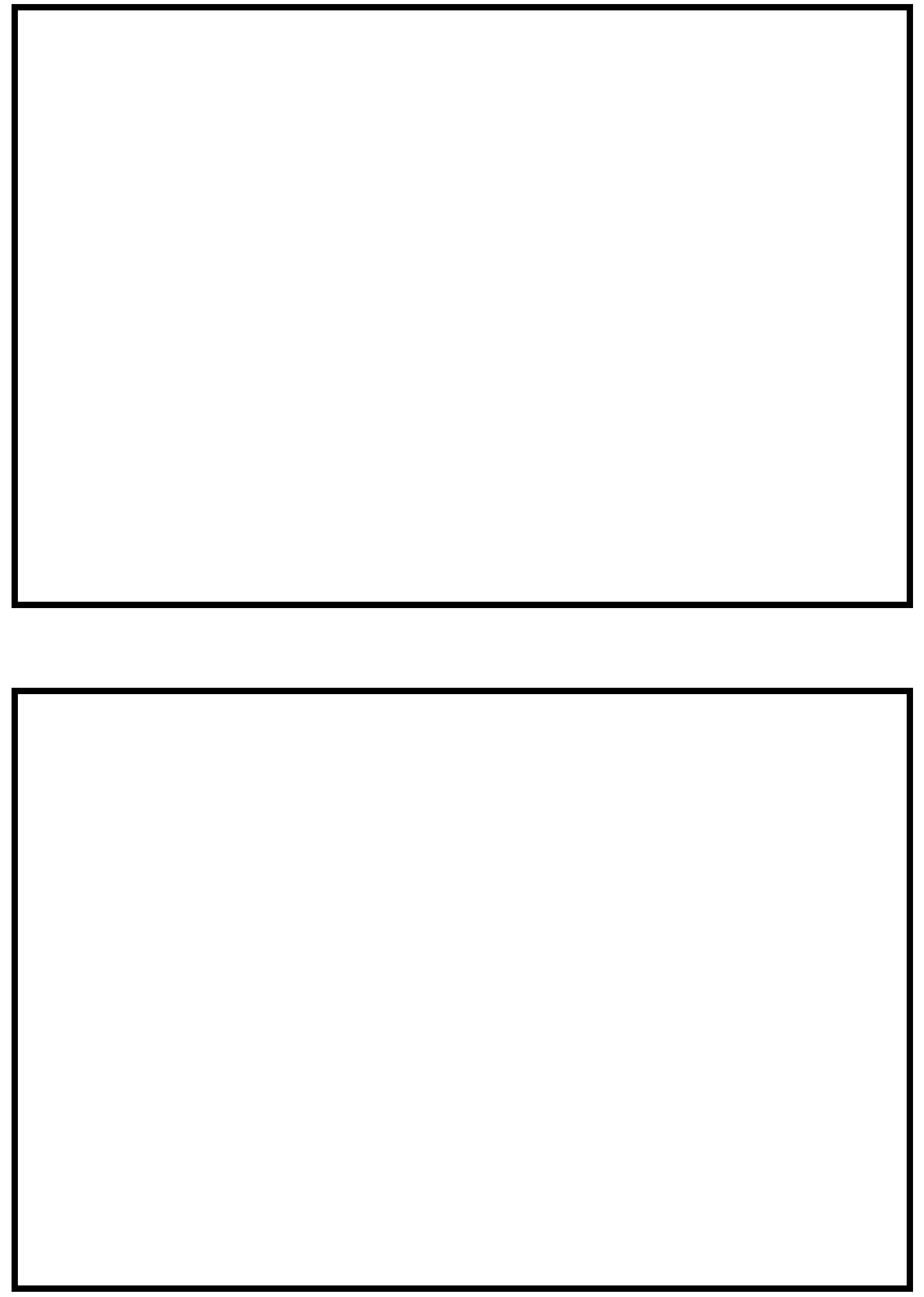


\section{LEVEL II SUMMARY}

\begin{tabular}{llllll} 
Structure Number & GLOVTH00030006 & & \multicolumn{3}{c}{ Barton River } \\
Stream & & & & \\
County & Orleans & Road & TH 3 & District & 9
\end{tabular}

\section{Description of Bridge}

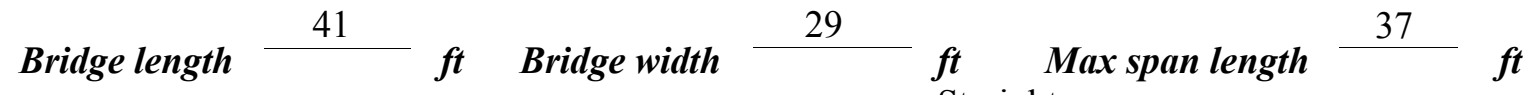
Alignment of bridge to road (on curve or straight)

Abutment type Vertical, concrete

Stone fill on abutment?

$$
\text { No }
$$

\section{Embankment type} Straight

Dato af incnortinn Sloping

$10 / 25-26 / 94$ Type-2, along the upstream right wingwall and type-3 stone fill along nacamintion af atom f fill the upstream left wingwall and both downstream wingwalls. Masonry walls are along both upstream banks.

Abutments and wingwalls are concrete. There is

$2 \mathrm{ft}$ of scour along the left abutment.

\section{Yes} 30

Is bridge skewed to flood flow according to No ' survey?

\section{Angle}

Through the study area the channel is constructed straight.

Debris accumulation on bridge at time of Level I or Level II site visit:

$$
\begin{gathered}
\text { Date of insnortion } \\
10 / 25 / 94 \\
\hline
\end{gathered}
$$

$10 / 26 / 94$

\section{Percent of ahmmal blocked inortzontaty}

Level I

Level II catch debris.

Potential for debris

Low. Furthermore, there is minimal constriction at the bridge site to

The upstream banks are constructed of masonry walls channelizing the flow--

Doscriho any fonturos noar ar at tho hridos that mav affort flow (includo ahsorvation dato) October 25, 1994. 


\section{Description of the Geomorphic Setting}

General topography The channel is located in a medium relief valley setting with narrow flood plains and steep valley walls.

Geomorphic conditions at bridge site: downstream (DS), upstream (US)

Date of inspection $\quad 10 / 25 / 94$

DS left: $\quad$ Steep channel bank to a narrow overbank

DS right: $\quad$ Steep channel bank to a mildly sloping overbank

US left: $\quad$ Steep channel bank to a mildly sloping overbank

US right: $\quad$ Steep channel bank to a wide, relatively flat overbank

\section{Description of the Channel}

\begin{tabular}{|c|c|c|c|}
\hline \multirow[b]{2}{*}{ Average top width } & & \multirow[b]{2}{*}{ Average depth } & \multirow[b]{2}{*}{ Walls/Boulders } \\
\hline & $\stackrel{\boldsymbol{f t}}{\text { Gravel / Boulders }}$ & & \\
\hline Predominant bed mo & & Bank material & Constructed straight \\
\hline
\end{tabular}

and stable with semi-alluvial to non-alluvial channel boundarië.

$10 / 25 / 94$

Vegetative co 1 Trees and brush on immediate bank with lawn further from channel.

DS left: $\quad$ Field grasses on immediate bank with pavement and lawns on overbank.

DS right: $\quad$ Trees and brush on immediate bank with lawn further from channel.

US left: $\quad$ Lawn with a few trees and a home.

US right: $\quad$ Yes

Do banks appear stable? -

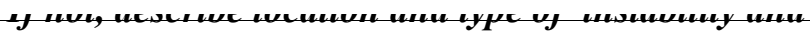

date of observatton.

about $100 \mathrm{ft}$ downstream of Glover bridge 6 .

Describe any obstructions in channel and date of observation. 


\section{Hydrology}

Drainage area $\frac{19.0}{\mathrm{mi}^{2}}$

Percentage of drainage area in physiographic provinces: (approximate)

Physiographic province/section New England/New England Upland
Percent of drainage area 100

Is drainage area considered rural or urban? Rural Describe any significant urbanization:

The site is located in the Village of Glover. However, the drainage is considered rural.

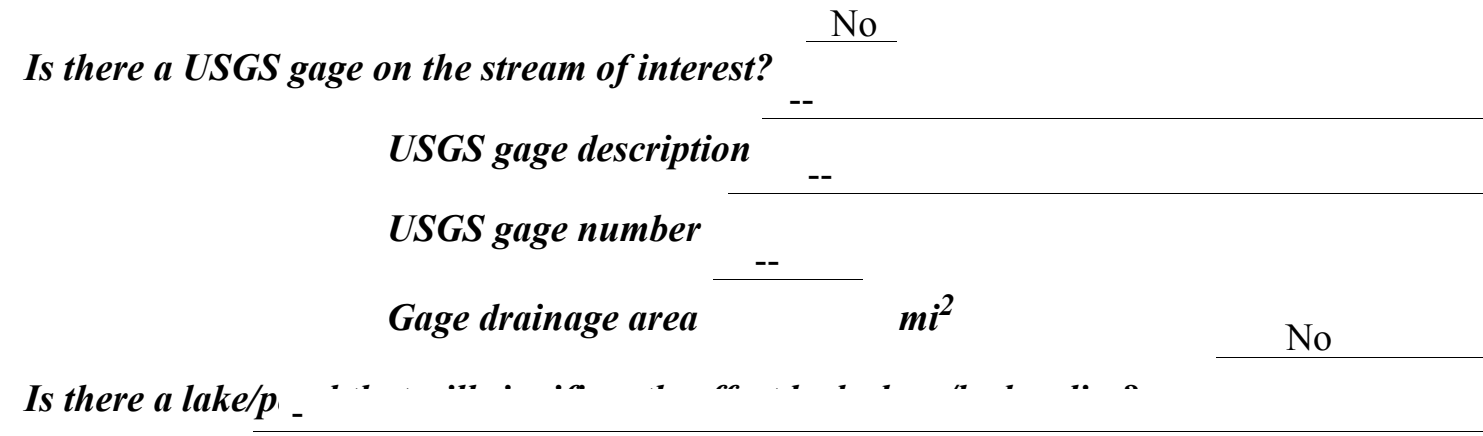

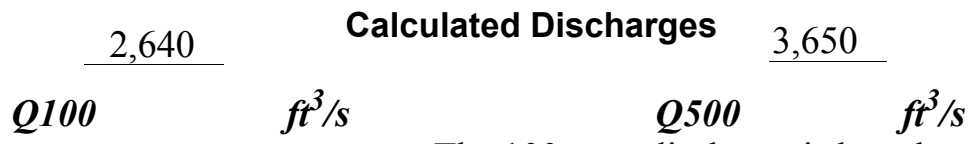

The 100-year discharge is based on a drainage area

relationship [(19.0/23.4)exp_0.7] with flood frequency estimates available from the Flood Insurance Study for the Town of Glover (Federal Emergency Management Agency, 1991).

Extrapolation to the 500-year discharge was done graphically based on the slopes of frequency curves developed from several empirical methods. The values used were within a range defined by various empirical methods (Benson, 1962; Johnson and Tasker, 1974; FHWA, 1983; Potter, 1957a\&b; Talbot, 1887). 


\section{Description of the Water-Surface Profile Model (WSPRO) Analysis}

Datum for WSPRO analysis (USGS survey, sea level, VTAOT plans)

USGS survey

Datum tie between USGS survey and VTAOT plans

Add $399.0 \mathrm{ft}$ to the USGS

arbitrary survey datum to obtain VAOT plans' datum.

Description of reference marks used to determine USGS datum. $\quad \underline{\mathrm{RM} 1 \text { is a chiseled X in a }}$

chiseled square on the downstream end of the left abutment (elev. $100.73 \mathrm{ft}$, arbitrary survey

datum). RM2 is a chiseled square on the upstream end of the right abutment (elev. $100.28 \mathrm{ft}$,

arbitrary survey datum). RM3 is a chiseled square on the upstream end of the right abutment of

the State Route 16 bridge (elev 100.98, arbitrary survey datum).

\section{Cross-Sections Used in WSPRO Analysis}

\begin{tabular}{|c|c|c|c|}
\hline${ }^{1}$ Cross-section & $\begin{array}{c}\text { Section } \\
\text { Reference } \\
\text { Distance } \\
\text { (SRD) in feet }\end{array}$ & $\begin{array}{l}{ }^{2} \text { Cross-section } \\
\text { development }\end{array}$ & Comments \\
\hline EVT16 & -224 & 1 & $\begin{array}{l}\text { Exit section of State Route } 16 \\
\text { bridge }\end{array}$ \\
\hline FVT16 & -159 & 2 & $\begin{array}{l}\text { Downstream Full-valley sec- } \\
\text { tion (Templated from EVT16) }\end{array}$ \\
\hline BVT16 & -159 & 1 & State Route 16 Bridge section \\
\hline RVT16 & -129 & 1 & $\begin{array}{l}\text { State Route } 16 \text { Road Grade sec- } \\
\text { tion }\end{array}$ \\
\hline AVT16 & -47 & 1 & Exit section of study site \\
\hline FULL1 & 0 & 2 & $\begin{array}{l}\text { Downstream Full-valley } \\
\text { section (Templated from } \\
\text { AVT16) }\end{array}$ \\
\hline BRIDG & 0 & 1 & Bridge section \\
\hline RDWAY & 22 & 1 & Road Grade section \\
\hline APPR1 & 69 & 2 & $\begin{array}{l}\text { Modelled Approach section } \\
\text { (Templated from APTEM) }\end{array}$ \\
\hline APTEM & 94 & 1 & $\begin{array}{l}\text { Approach section as surveyed } \\
\text { (Used as a template) }\end{array}$ \\
\hline
\end{tabular}

${ }^{1}$ For location of cross-sections see plan-view sketch included with Level I field form, appendix E. 


\section{Data and Assumptions Used in WSPRO Model}

Hydraulic analyses of the reach were done by use of the Federal Highway Administration's WSPRO step-backwater computer program (Shearman and others, 1986, and Shearman, 1990). The analyses reported herein reflect conditions existing at the site at the time of the study. Furthermore, in the development of the model it was necessary to assume no accumulation of debris or ice at the site. Results of the hydraulic model are presented in the Bridge Hydraulic Summary, appendix B, and figure 7.

Channel roughness factors (Manning's " $n$ ") used in the hydraulic model were estimated using field inspections at each cross section following the general guidelines described by Arcement and Schneider (1989). Final adjustments to the values were made during the modelling of the reach. Channel " $n$ " values for the reach ranged from 0.045 to 0.055 , and overbank " $n$ " values ranged from 0.045 to 0.093 .

Due to the proximity of the State Route 16 bridge downstream of Glover bridge 6, it is likely that backwater from the State Route 16 bridge will affect hydraulics at Glover bridge 6 over a wide range of discharges. Therefore, the State Route 16 bridge was included in this model. Normal depth at the most downstream section (EVT16) was assumed as the starting water surface. This depth was computed by use of the slope-conveyance method outlined in the user's manual for WSPRO (Shearman, 1990). The slope used was $0.013 \mathrm{ft} / \mathrm{ft}$, which was measured from the 100-year water-surface profile downstream of the State Route 16 bridge over the Barton River in the Flood Insurance Study for the Town of Glover (Federal Emergency Management Agency, 1991). Since normal depth for the 500-year discharge at section EVT16 was computed only $0.1 \mathrm{ft}$ below critical depth, critical depth was allowed for this discharge.

The surveyed approach section (APTEM) was moved along the approach channel slope $(0.019 \mathrm{ft} / \mathrm{ft})$ to establish the modelled approach section (APPR1), one bridge length upstream of the upstream face as recommended by Shearman and others (1986). This location provides a consistent method for determining scour variables. 


\section{Bridge Hydraulics Summary}

\begin{tabular}{llll} 
Average bridge embankment elevation & \multicolumn{1}{c}{100.9} & $f t$ \\
\cline { 3 - 3 } Average low steel elevation & 98.6 & $\boldsymbol{f t}$
\end{tabular}

100-year discharge $\quad 2,640 \quad \mathrm{ft}^{3} / \mathrm{s}$

Water-surface elevation in bridge opening $\quad \begin{array}{lll}98.8 \quad \boldsymbol{f t} \\ \end{array}$

Road overtopping? ___ Y Discharge over road__ $847,3 / \mathrm{s}$

\begin{tabular}{llc} 
Area of flow in bridge opening & $192 \quad \boldsymbol{f t}^{2}$ \\
\cline { 2 - 3 } Average velocity in bridge opening & 9.2 & $\boldsymbol{f t} / \mathrm{s}$
\end{tabular}

$\begin{array}{llll}\text { Maximum WSPRO tube velocity at bridge } & 10.8 \mathrm{ft} / \mathrm{s}\end{array}$

Water-surface elevation at Approach section with bridge 101.9

Water-surface elevation at Approach section without bridge $\quad 100.0$

Amount of backwater caused by bridge

1.9 it

500-year discharge $\quad 3,650 \quad \mathrm{ft}^{3} / \mathrm{s}$

Water-surface elevation in bridge opening

$98.8 f t$

Road overtopping? ___ Y Discharge over road _ _ 1,990 , is

Area of flow in bridge opening $\quad 192 \quad \mathrm{ft}^{2}$

Average velocity in bridge opening $\quad 9.0 \mathrm{ft} / \mathrm{s}$

Maximum WSPRO tube velocity at bridge 10.6 , 's

Water-surface elevation at Approach section with bridge 102.8

Water-surface elevation at Approach section without bridge $\quad 100.9$

Amount of backwater caused by bridge $\quad 1.9$.t

Incipient overtopping discharge $\quad 1,590 \mathrm{ft}^{3} / \mathrm{s}$

Water-surface elevation in bridge opening $\quad 98.8 \quad$ t

Area of flow in bridge opening $\quad 192 \quad \mathrm{ft}^{2}$

$\begin{array}{lll}\text { Average velocity in bridge opening } & 8.3 \quad \mathrm{ft} / \mathrm{s}\end{array}$

Maximum WSPRO tube velocity at bridge $\quad 9.8 \mathrm{ft} / \mathrm{s}$

Water-surface elevation at Approach section with bridge

Water-surface elevation at Approach section without bridge

Amount of backwater caused by bridge $\quad 1.9$,t

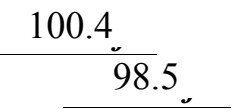




\section{Scour Analysis Summary}

\section{Special Conditions or Assumptions Made in Scour Analysis}

Scour depths were computed using the general guidelines described in Hydraulic Engineering Circular 18 (Richardson and Davis, 1995). Scour depths were calculated assuming an infinite depth of erosive material and a homogeneous particle-size distribution. The results of the scour analyses for the 100- and 500-year discharges are presented in tables 1 and 2 and the scour depths are shown graphically in figure 8 .

At this site, the 100-year, the 500-year, and the incipient roadway-overtopping discharges resulted in orifice flow. Contraction scour at bridges with orifice flow is best estimated by use of the Chang pressure-flow scour equation (oral communication, J. Sterling Jones, October 4, 1996). Thus, contraction scour was computed by use of the Chang equation (Richardson and Davis, 1995, p. 145-146). The streambed armoring depths computed suggest that armoring will not limit the depth of contraction scour.

For comparison, contraction scour also was computed by use of the Laursen clearwater contraction scour equation (Richardson and Davis, 1995, p. 32, equation 20) and the Umbrell pressure-flow equation (Richardson and Davis, 1995, p. 144). Results from these computations are presented in appendix F. Furthermore, for the incipient-overtopping discharge, which resulted in unsubmerged orifice flow, contraction scour was computed by substituting an estimate for the depth of flow at the downstream bridge face in the contraction scour equations. Results with respect to this substitution also are provided in appendix F.

Abutment scour was computed by use of the HIRE equation (Richardson and Davis, 1995, p. 49, equation 29) because the HIRE equation is recommended when the length to depth ratio of the embankment blocking flow exceeds 25 . The variables used by the HIRE abutment-scour equation include the Froude number of the flow approaching the embankments, the length of the embankment blocking flow, and the depth of flow approaching the embankment less any roadway overtopping. 


\section{Scour Results}

Contraction scour:

Main channel

Live-bed scour

Clear-water scour

Depth to armoring

Left overbank

Right overbank

Local scour:

Abutment scour

Left abutment

Right abutment

Pier scour

Pier 1

Pier 2

Pier 3 100-year
discharge 500-year discharge

(Scour depths in feet)

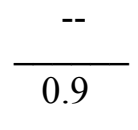

$3.6^{-}$
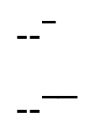


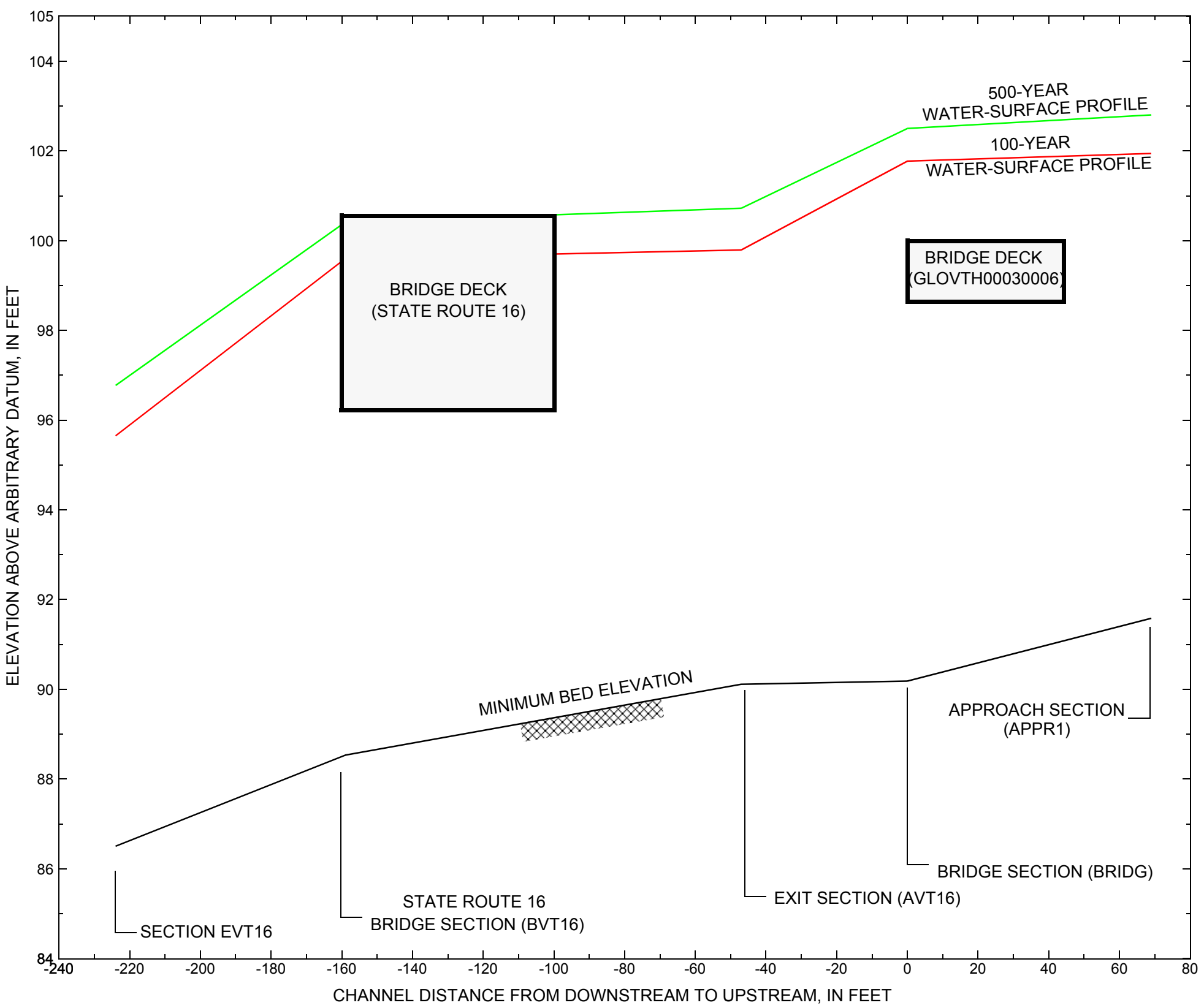

Figure 7. Water-surface profiles for the 100- and 500-year discharges at structure GLOVTH00030006 on Town Highway 3, crossing the Barton River, Glover, Vermont. 


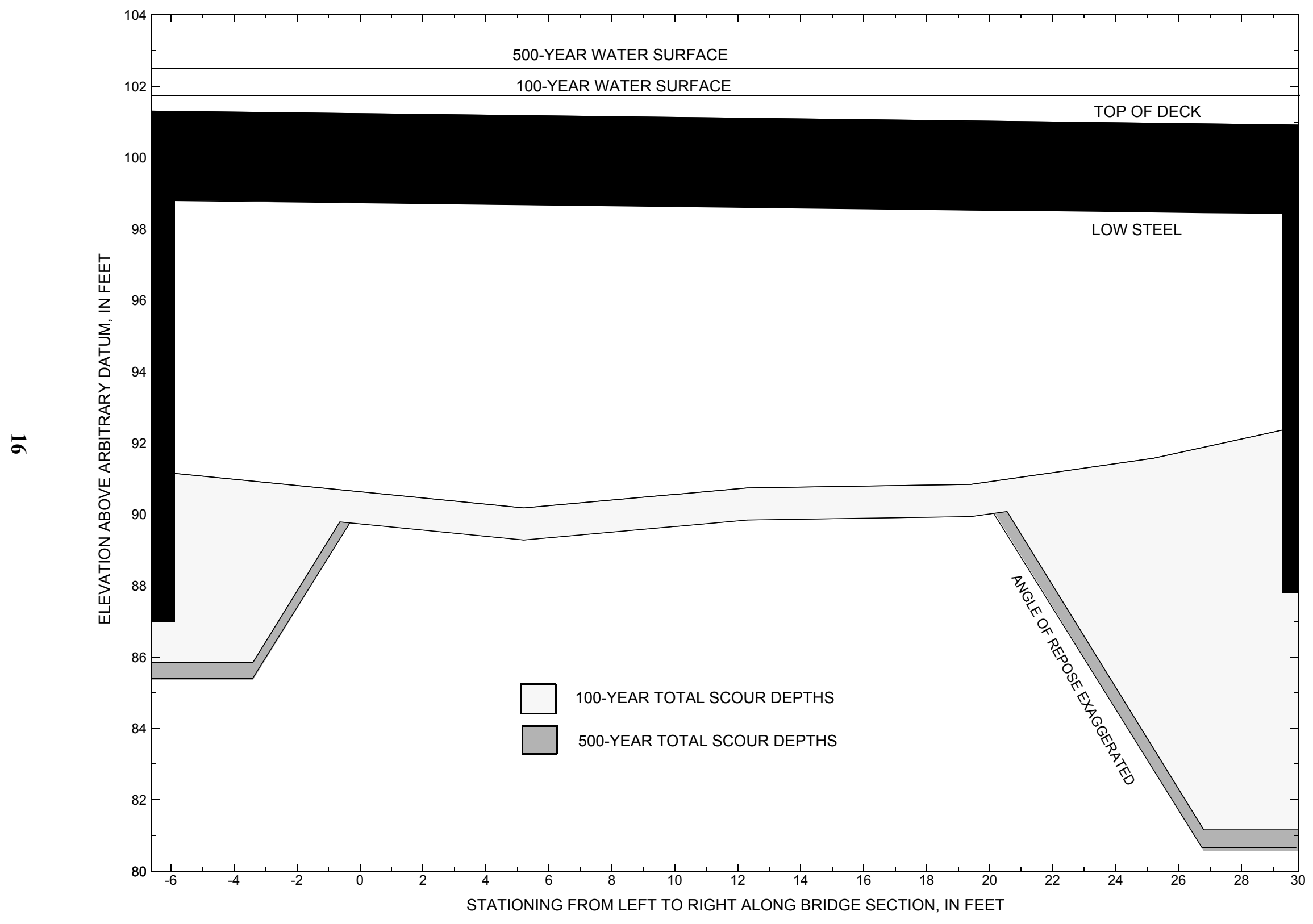

Figure 8. Scour elevations for the 100- and 500-year discharges at structure GLOVTH00030006 on Town Highway 3, crossing the Barton River, Glover, Vermont. 
Table 1. Remaining footing/pile depth at abutments for the 100-year discharge at structure GLOVTH00030006 on Town Highway 3, crossing the Barton River, Glover, Vermont.

[VTAOT, Vermont Agency of Transportation; --, no data]

\begin{tabular}{|c|c|c|c|c|c|c|c|c|c|c|c|}
\hline Description & Station $^{1}$ & $\begin{array}{l}\text { VTAOT } \\
\text { minimum } \\
\text { low-chord } \\
\text { elevation } \\
\text { (feet) }\end{array}$ & $\begin{array}{l}\text { Surveyed } \\
\text { minimum } \\
\text { low-chord } \\
\text { elevation } \\
\quad \text { (feet) }\end{array}$ & $\begin{array}{c}\text { Bottom of } \\
\text { footing/pile } \\
\text { elevation }{ }^{2} \\
\text { (feet) }\end{array}$ & $\begin{array}{c}\text { Channel } \\
\text { elevation at } \\
\text { abutment/ } \\
\text { pier }{ }^{2} \\
\text { (feet) }\end{array}$ & $\begin{array}{l}\text { Contraction } \\
\text { scour depth } \\
\text { (feet) }\end{array}$ & $\begin{array}{l}\text { Abutment } \\
\text { scour } \\
\text { depth } \\
\text { (feet) }\end{array}$ & $\begin{array}{l}\text { Pier } \\
\text { scour } \\
\text { depth } \\
\text { (feet) }\end{array}$ & $\begin{array}{l}\text { Depth of } \\
\text { total scour } \\
\text { (feet) }\end{array}$ & $\begin{array}{c}\text { Elevation of } \\
\text { scour }^{2} \\
\text { (feet) }\end{array}$ & $\begin{array}{c}\text { Remaining } \\
\text { footing/pile } \\
\text { depth } \\
\text { (feet) }\end{array}$ \\
\hline \multicolumn{12}{|c|}{100 -year discharge is 2,640 cubic-feet per second } \\
\hline Left abutment & -6.1 & 497.7 & 98.8 & 87.0 & 91.2 & 0.9 & 4.4 & -- & 5.3 & 85.9 & -1.1 \\
\hline Right abutment & 29.3 & 497.3 & 98.4 & 87.8 & 92.4 & 0.9 & 10.3 & -- & 11.2 & 81.2 & -6.6 \\
\hline
\end{tabular}

1.Measured along the face of the most constricting side of the bridge.

2.Arbitrary datum for this study.

Table 2. Remaining footing/pile depth at abutments for the 500-year discharge at structure GLOVTH00030006 on Town Highway 3, crossing the Barton River, Glover, Vermont.

[VTAOT, Vermont Agency of Transportation; --, no data]

\begin{tabular}{|c|c|c|c|c|c|c|c|c|c|c|c|}
\hline Description & Station $^{1}$ & $\begin{array}{l}\text { VTAOT } \\
\text { minimum } \\
\text { low-chord } \\
\text { elevation } \\
\text { (feet) }\end{array}$ & $\begin{array}{c}\text { Surveyed } \\
\text { minimum } \\
\text { low-chord } \\
\text { elevation } \\
\text { (feet) }\end{array}$ & $\begin{array}{c}\text { Bottom of } \\
\text { footing/pile } \\
\text { elevation } \\
\text { (feet) }\end{array}$ & $\begin{array}{c}\text { Channel } \\
\text { elevation at } \\
\text { abutment/ } \\
\text { pier }^{2} \\
\text { (feet) }\end{array}$ & $\begin{array}{l}\text { Contraction } \\
\text { scour depth } \\
\text { (feet) }\end{array}$ & $\begin{array}{c}\text { Abutment } \\
\text { scour } \\
\text { depth } \\
\text { (feet) }\end{array}$ & $\begin{array}{l}\text { Pier } \\
\text { scour } \\
\text { depth } \\
\text { (feet) }\end{array}$ & $\begin{array}{l}\text { Depth of } \\
\text { total scour } \\
\text { (feet) }\end{array}$ & $\begin{array}{c}\text { Elevation of } \\
\text { scour }^{2} \\
\text { (feet) }\end{array}$ & $\begin{array}{c}\text { Remaining } \\
\text { footing/pile } \\
\text { depth } \\
\text { (feet) }\end{array}$ \\
\hline \multicolumn{12}{|c|}{500 -year discharge is 3,650 cubic-feet per second } \\
\hline Left abutment & -6.1 & 497.7 & 98.8 & 87.0 & 91.2 & 0.6 & 5.2 & -- & 5.8 & 85.4 & -1.6 \\
\hline Right abutment & 29.3 & 497.3 & 98.4 & 87.8 & 92.4 & 0.6 & 11.2 & -- & 11.8 & 80.6 & -7.2 \\
\hline
\end{tabular}

1.Measured along the face of the most constricting side of the bridge.

2.Arbitrary datum for this study. 


\section{SELECTED REFERENCES}

Arcement, G.J., Jr., and Schneider, V.R., 1989, Guide for selecting Manning's roughness coefficients for natural channels and flood plains:

U.S. Geological Survey Water-Supply Paper 2339, 38 p.

Barnes, H.H., Jr., 1967, Roughness characteristics of natural channels: U.S. Geological Survey Water-Supply Paper 1849,213 p.

Benson, M. A., 1962, Factors Influencing the Occurrence of Floods in a Humid Region of Diverse Terrain: U.S. Geological Survey WaterSupply Paper 1580-B, 64 p.

Brown, S.A. and Clyde, E.S., 1989, Design of riprap revetment: Federal Highway Administration Hydraulic Engineering Circular No. 11, Publication FHWA-IP-89-016, 156 p.

Federal Emergency Management Agency, 1991, Flood Insurance Study, Town of Glover, Orleans County, Vermont: Washington, D.C., August 5, 1991.

Federal Highway Administration, 1983, Runoff estimates for small watersheds and development of sound design: Federal Highway Administration Report FHWA-RD-77-158.

Federal Highway Administration, 1993, Stream Stability and Scour at Highway Bridges: Participant Workbook: Federal Highway Administration Report FHWA-HI-91-011.

Froehlich, D.C., 1989, Local scour at bridge abutments in Ports, M.A., ed., Hydraulic Engineering--Proceedings of the 1989 National Conference on Hydraulic Engineering: New York, American Society of Civil Engineers, p. 13-18.

Hayes, D.C.,1993, Site selection and collection of bridge-scour data in Delaware, Maryland, and Virginia: U.S. Geological Survey WaterResources Investigation Report 93-4017, 23 p.

Interagency Advisory Committee on Water Data, 1982, Guidelines for determining flood flow frequency: U.S. Geological Survey, Bulletin 17B of the Hydrology Subcommittee, 190 p.

Johnson, C.G. and Tasker, G.D.,1974, Progress report on flood magnitude and frequency of Vermont streams: U.S. Geological Survey OpenFile Report 74-130, 37 p.

Lagasse, P.F., Schall, J.D., Johnson, F., Richardson, E.V., Chang, F., 1995, Stream Stability at Highway Structures: Federal Highway Administration Hydraulic Engineering Circular No. 20, Publication FHWA-IP-90-014, 144 p.

Laursen, E.M., 1960, Scour at bridge crossings: Journal of the Hydraulics Division, American Society of Civil Engineers, v. 86, no. HY2, p. 39-53.

Potter, W. D., 1957a, Peak rates of runoff in the Adirondack, White Mountains, and Maine woods area, Bureau of Public Roads

Potter, W. D., 1957b, Peak rates of runoff in the New England Hill and Lowland area, Bureau of Public Roads

Richardson, E.V. and Davis, S.R., 1995, Evaluating scour at bridges: Federal Highway Administration Hydraulic Engineering Circular No. 18, Publication FHWA-IP-90-017, 204 p.

Richardson, E.V., Simons, D.B., and Julien, P.Y., 1990, Highways in the river environment: Federal Highway Administration Publication FHWA-HI-90-016.

Ritter, D.F., 1984, Process Geomorphology: W.C. Brown Co., Debuque, Iowa, 603 p.

Shearman, J.O., 1990, User's manual for WSPRO--a computer model for water surface profile computations: Federal Highway Administration Publication FHWA-IP-89-027, 187 p.

Shearman, J.O., Kirby, W.H., Schneider, V.R., and Flippo, H.N., 1986, Bridge waterways analysis model; research report: Federal Highway Administration Publication FHWA-RD-86-108, 112 p.

Talbot, A.N., 1887, The determination of water-way for bridges and culverts.

U.S. Geological Survey, 1986, Crystal Lake, Vermont 7.5 Minute Series quadrangle map: U.S. Geological Survey Topographic Maps, Scale 1:24,000. 


\section{APPENDIX A: \\ WSPRO INPUT FILE}




\section{WSPRO INPUT FILE}

Q

SK

*

J3

*

XS

GR

GR

GR

GR

$\mathrm{N}$

SA

*

XS

*

BR

GR

GR

GR

$\mathrm{N}$

CD

*

$\mathrm{XR}$

GR

GR

GR

AS

GR

GR

GR

GR

GR

$\mathrm{N}$

SA

*

XS

*

$\mathrm{BR}$

GR

GR

GR

$\mathrm{N}$

CD

*

$\mathrm{XR}$

GR

GR

GR

GR

*

XT
U.S. Geological Survey WSPRO Input File glov006.wsp Hydraulic analysis for structure GLOVTH00030006 Date: 01-MAY-96 Glover Br 6, th 3, Barton R.

$$
\begin{array}{lrr}
2640 & 3650 & 1590 \\
0.013 & 0.013 & 0.013
\end{array}
$$

$\begin{array}{lllllllllllllllllllll}6 & 29 & 30 & 552 & 553 & 551 & 5 & 16 & 17 & 13 & 3 & * & 15 & 14 & 23 & 21 & 11 & 12 & 4 & 7 & 3\end{array}$

\begin{tabular}{|c|c|c|c|c|c|c|c|}
\hline-226.8 & 108.95 & -182.9, & 98.16 & -50.2, & 97.84 & -34.2 , & 94.80 \\
\hline 0.0, & 94.65 & 7.8, & 88.82 & 9.8, & 88.73 & 14.1, & 87.69 \\
\hline 21.6 & 86.45 & 26.7, & 87.46 & 27.2 & 88.70 & 38.2, & 96.16 \\
\hline 69.2 , & 98.10 & 113.9 , & 101.96 & 191.8, & 108.44 & & \\
\hline 0.065 & & 45 & 0.045 & & & & \\
\hline
\end{tabular}

$$
\text { EVT16 }-224
$$

\begin{tabular}{|c|c|c|c|c|c|c|}
\hline 0.0, & 95.97 & 4.9, & 93.13 & 13.7, & 91.14 & 89.93 \\
\hline & .87 & 30.5 & 88.53 & 40.7 & 88.58 & 88.86 \\
\hline & 89.97 & 50.7 & 93.69 & 60.4 & 96.27 & 0.0 \\
\hline
\end{tabular}

FVT16 - 159 * * * 0.03

BVT16 $-159 \quad 96.12 \quad 45$

0.050

$\begin{array}{lllll}3 & 61 & 7.9 & 98\end{array}$

RVT16

$-12961$

$$
-226.8,108.95
$$

$-182.9, \quad 98.16$

$-8.1, \quad 99.24$

$143.6,100.45$

$0.0,100.29$

$65.6,100.82$

$92.1,100.01$

$299.2,113.08$

AVT16 -47

$-226.8,108.95$

$-27.9,96.36$

$-126.2, \quad 96.84$

$-68.1, \quad 95.93$

$-55.7, \quad 96.94$

$0.0,91.16$

$3.8,90.51$

$12.4,90.11$

$-8.9, \quad 96.00$

$21.4, \quad 91.12$

$23.5, \quad 91.67$

$31.8, \quad 95.82$

$44.2,100.53$

$76.4,100.27$

$110.3,100.97$

$140.8,100.48 \quad 150.0,101.76$

$194.7,104.43$

0.06

$$
-8.9
$$

0.055

0.06

FULL1

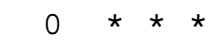

0.0133

BRIDG

0
-6.1
12.3
29.3
0.050
4

98.58

98.76

90.74

98.40

43.5

4.7

45.0

$$
-6.0 \text {, }
$$

19.4 ,

92.14

90.84

$-5.6, \quad 91.15$

$25.2, \quad 91.57$

$5.2, \quad 90.18$

$-6.1, \quad 98.76$

RDWAY

$22 \quad 29$

$-170.6,106.36$

$0.0,101.08$

$-107.0,103.11$

$20.5,100.94$

$-56.8,101.66$

$-17.0,101.13$

$76.4,100.27$

$110.3,100.97$

$35.7,100.81$

$35.7,100.72$

$194.7,104.43$

APTEM

94 


\section{WSPRO INPUT FILE (continued)}

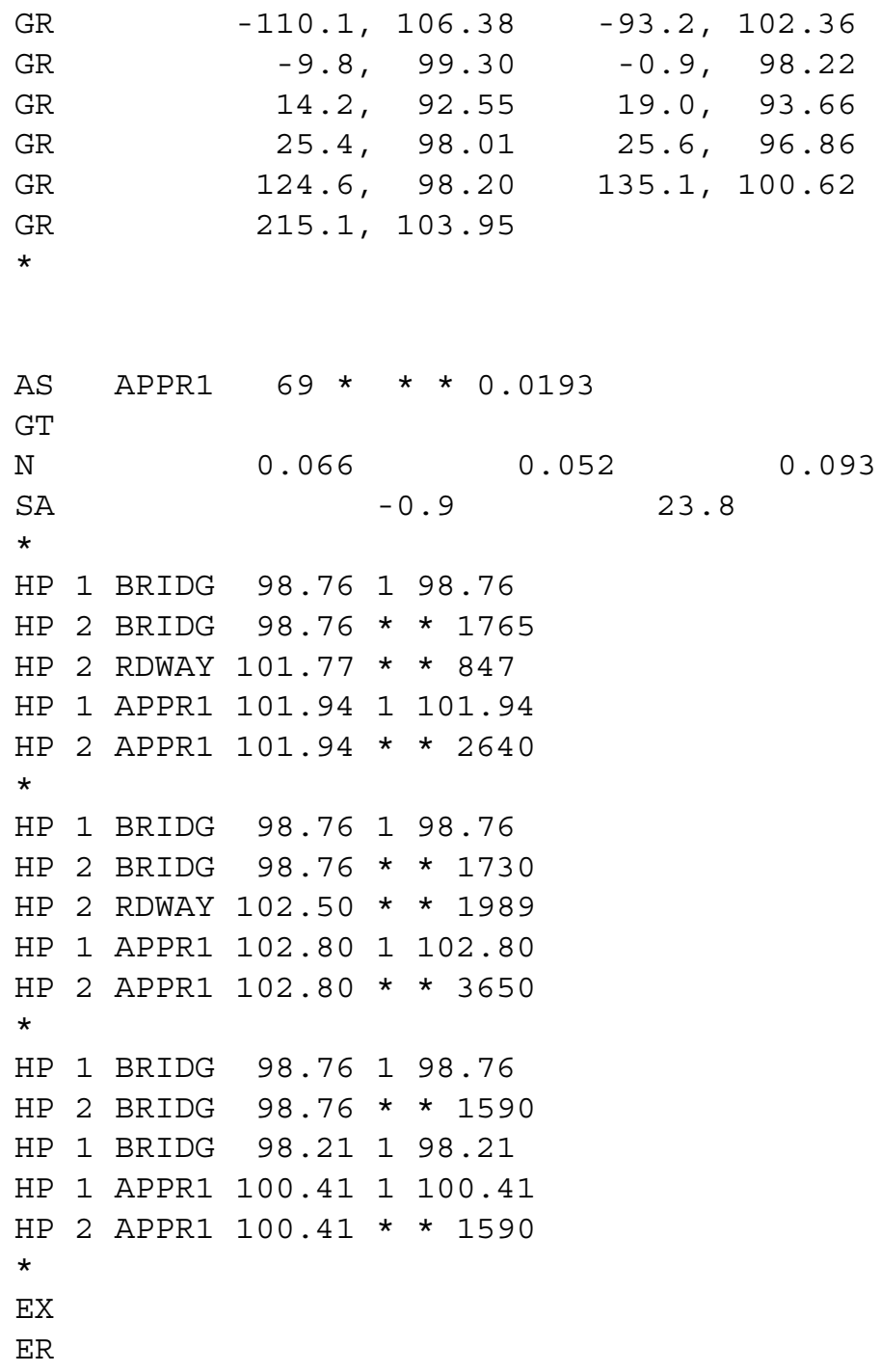

GR

GR

GR

GR

GR

GR

*

AS

GT

$\mathrm{N}$

SA

*

HP 1 BRIDG 98.76198 .76

HP 2 BRIDG 98.76 * * 1765

HP 2 RDWAY 101.77 * * 847

HP 1 APPR1 101.941101 .94

HP 2 APPR1 101.94 * * 2640

*

HP 1 BRIDG 98.76198 .76

HP 2 BRIDG 98.76 * * 1730

HP 2 RDWAY 102.50 * * 1989

$\mathrm{HP} 1$ APPRI 102.801102 .80

HP 2 APPRI 102.80 * * 3650

*

HP 1 BRIDG 98.76198 .76

HP 2 BRIDG 98.76 * * 1590

HP 1 BRIDG 98.21198 .21

HP 1 APPR1 100.411100 .41

HP 2 APPR 100.41 * * 1590

*

EX

ER

$$
\begin{array}{rr}
-0.9, & 98.22 \\
19.0, & 93.66 \\
25.6, & 96.86 \\
135.1, & 100.62
\end{array}
$$$$
-93.2, \quad 102.36
$$

0.093

23.8

$-46.0, \quad 100.31$

$0.1, \quad 92.78$

$23.4, \quad 94.95$

$28.7, \quad 96.90$

$162.5,101.57$
$-25.2,100.58$

$7.4,92.06$

$23.8,98.35$

$53.6, \quad 96.95$

$181.9,100.98$ 


\section{APPENDIX B: \\ WSPRO OUTPUT FILE}




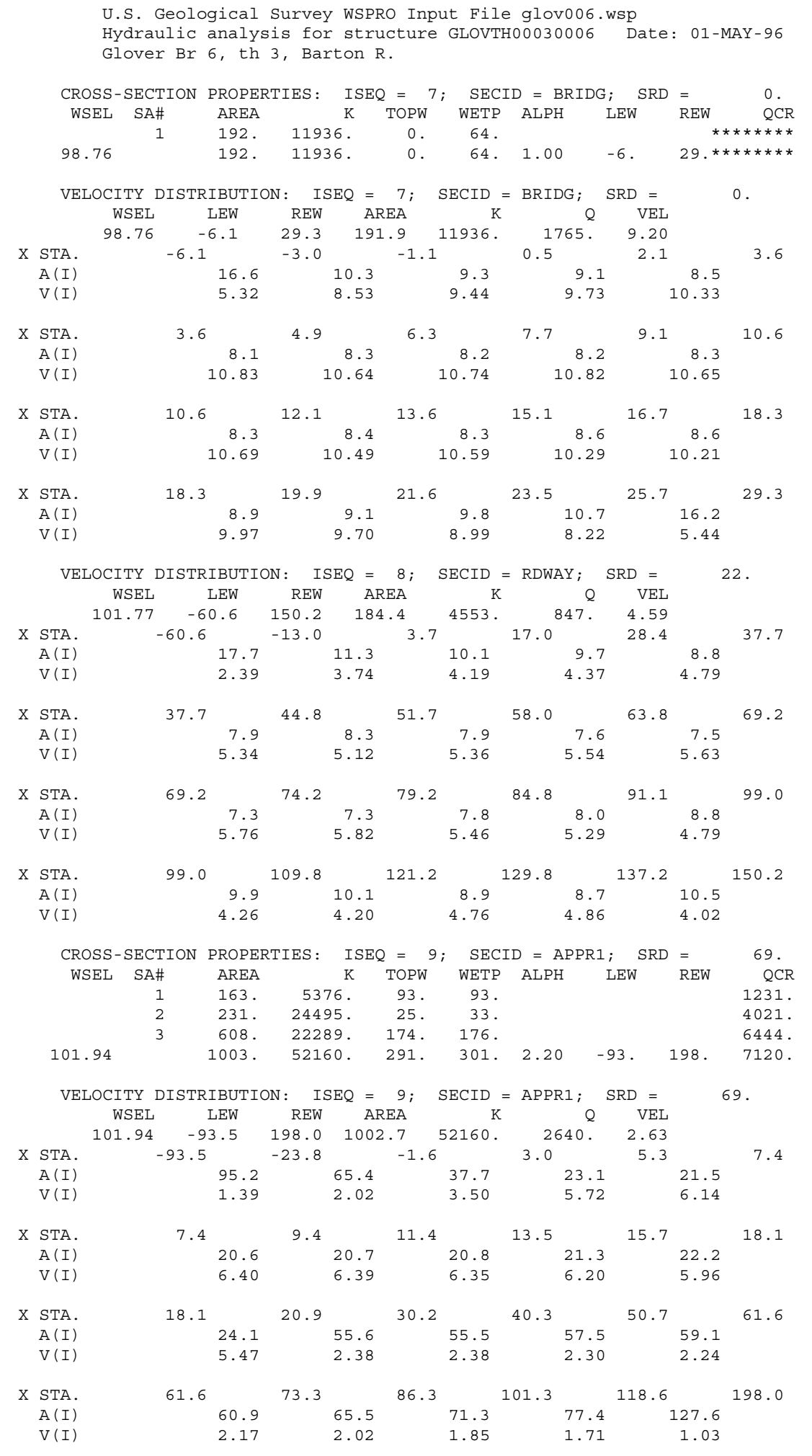




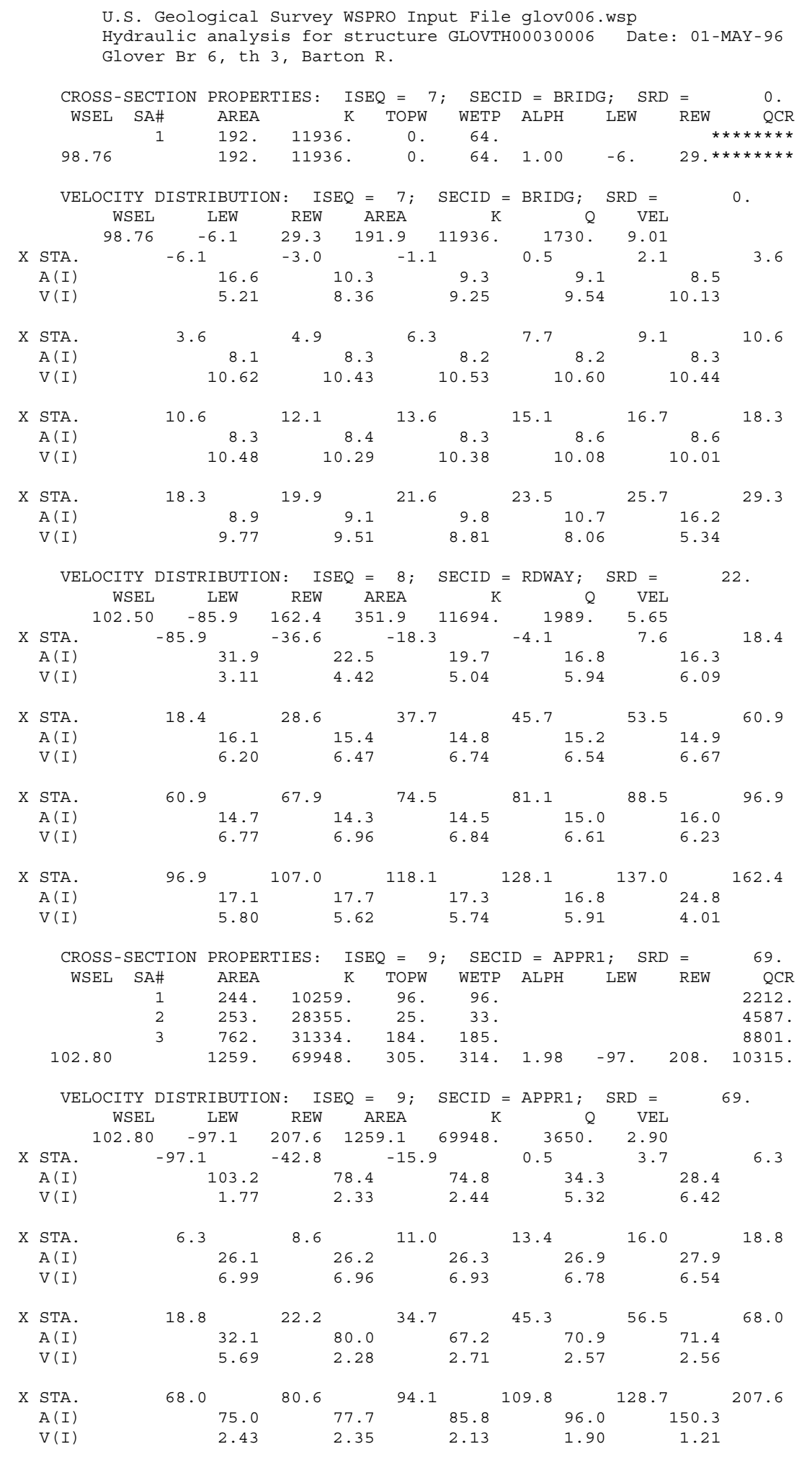


WSPRO OUTPUT FILE (continued)

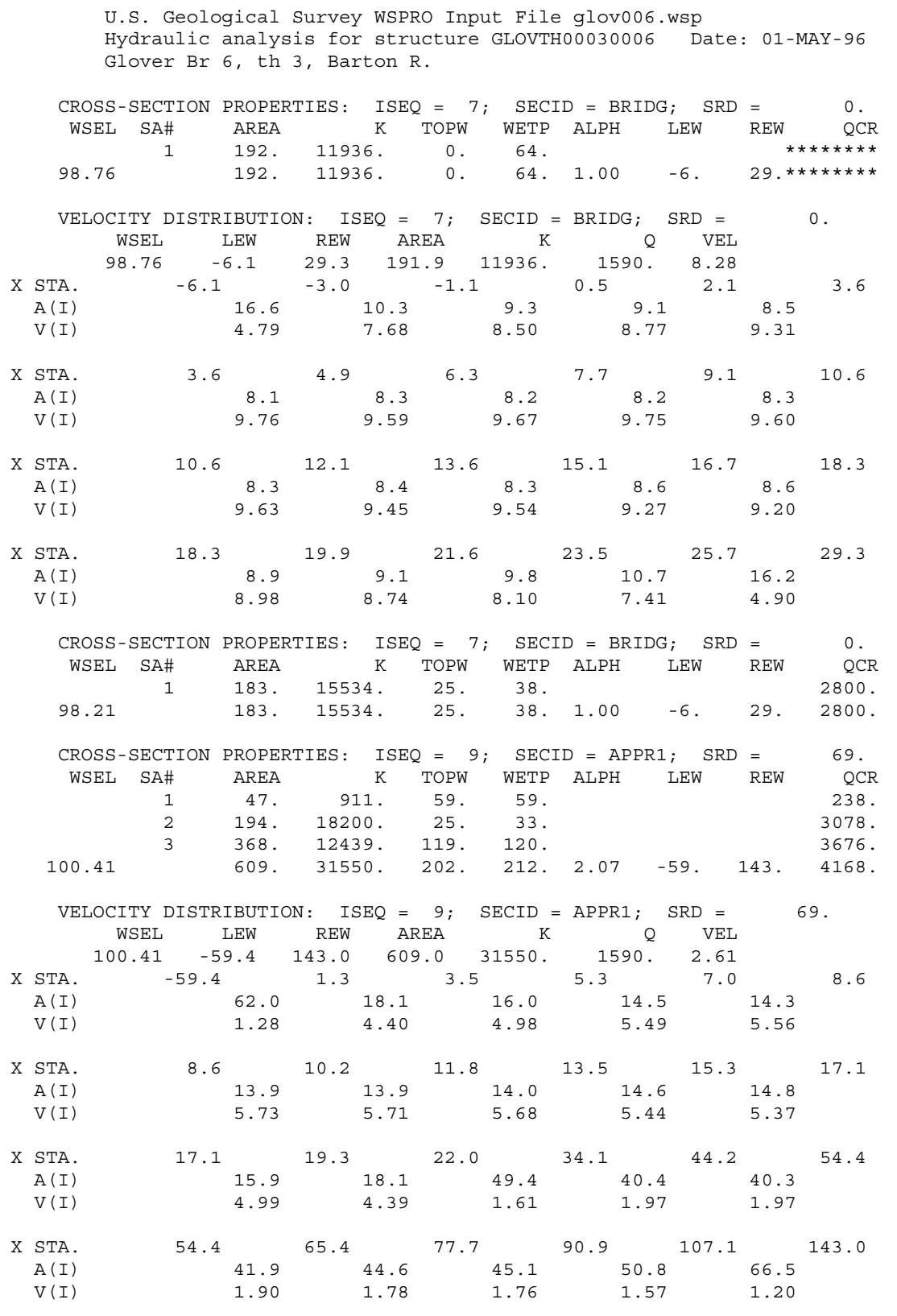


WSPRO OUTPUT FILE (continued)

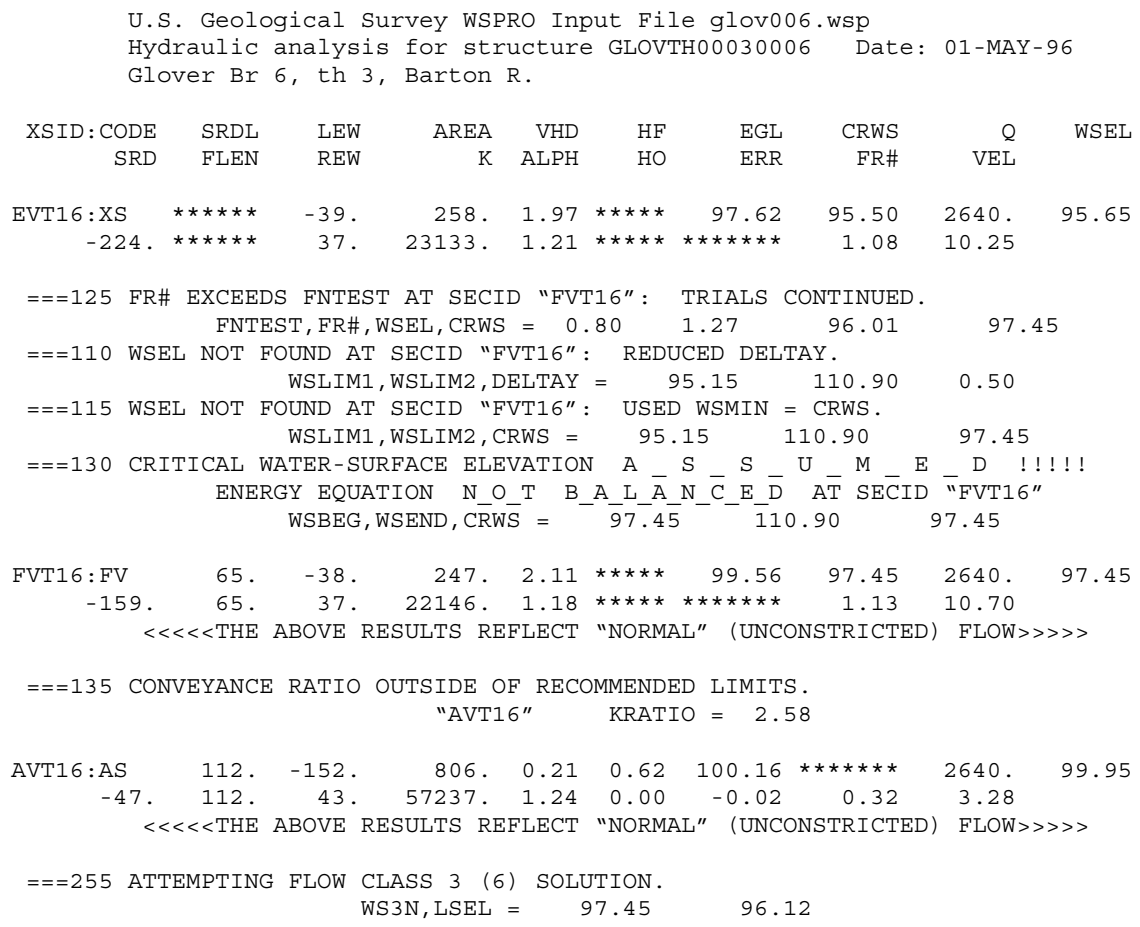


WSPRO OUTPUT FILE (continued)

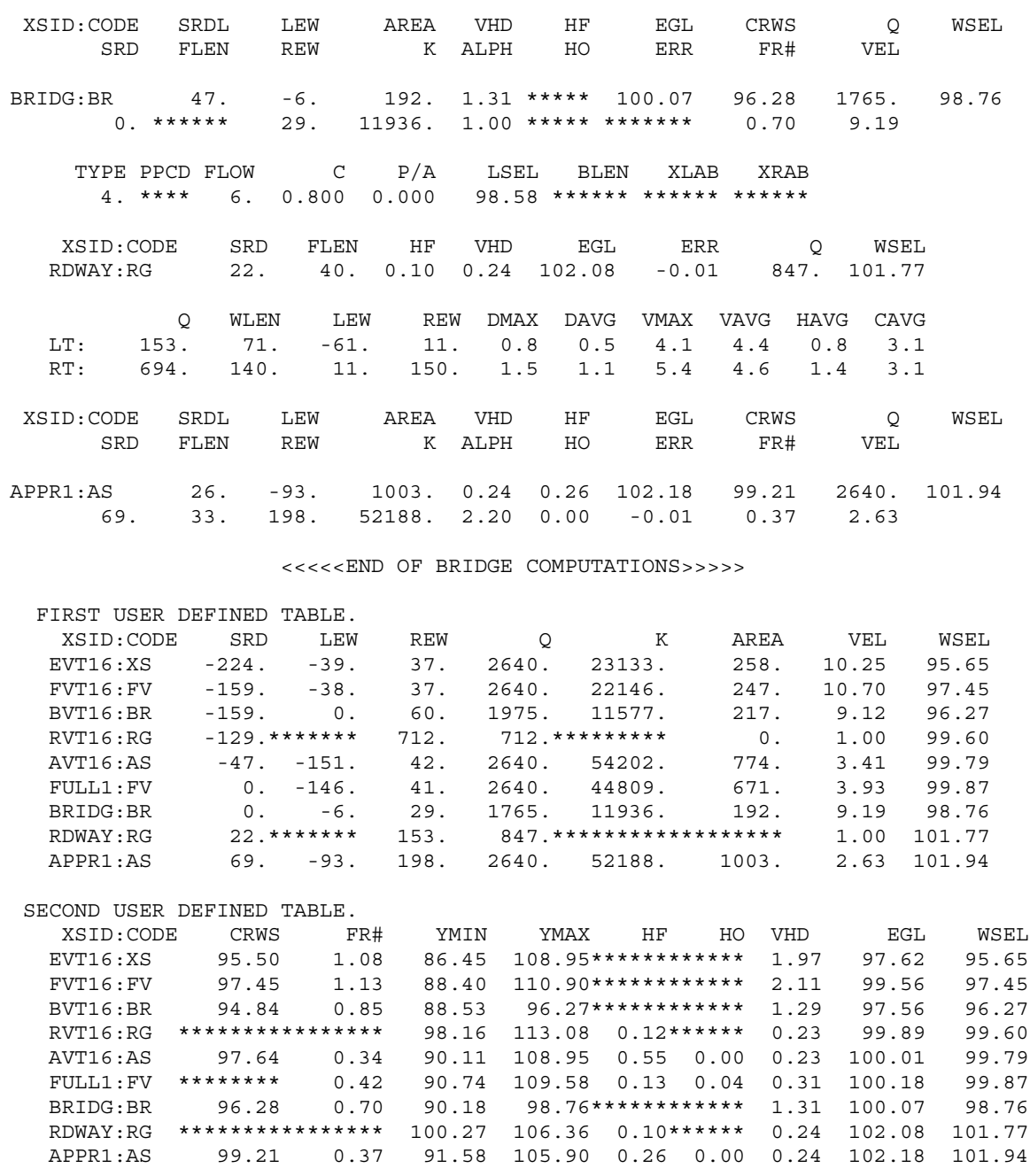

U.S. Geological Survey WSPRO Input File glov006.wsp

Hydraulic analysis for structure GLOVTH00030006 Date: 01-MAY-96

Glover $\operatorname{Br} 6$, th 3, Barton R.

$==015$ WSI IN WRONG FLOW REGIME AT SECID "EVT16": USED WSI = CRWS.

WSI, CRWS $=96.73 \quad 96.77$

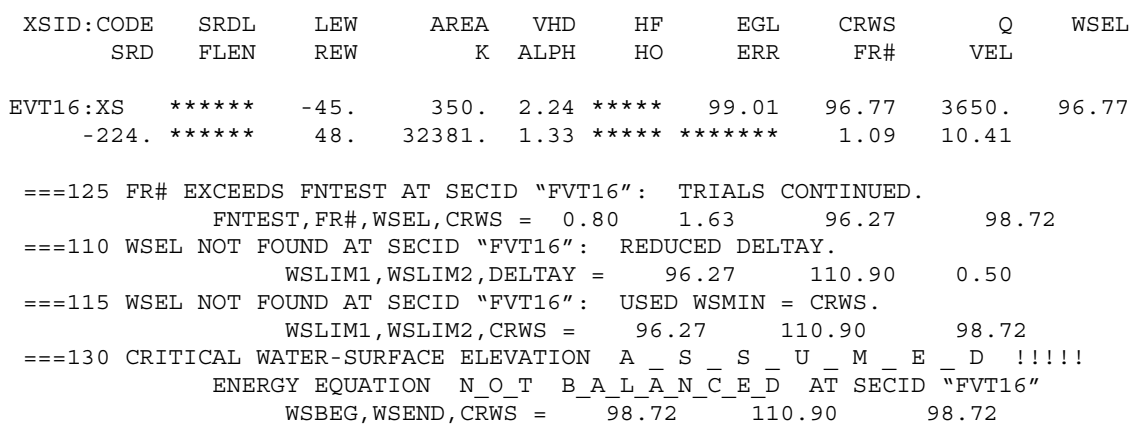

$\begin{array}{lllllllll}\text { FVT16:FV } & 65 . & -45 . & 350 . & 2.24 * * * * * & 100.96 & 98.72 & 3650 . & 98.72\end{array}$

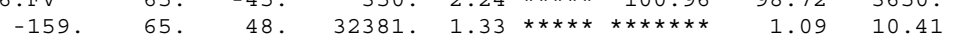
$\ll<<$ THE ABOVE RESULTS REFLECT "NORMAL" (UNCONSTRICTED) FLOW >>>>

$===135$ CONVEYANCE RATIO OUTSIDE OF RECOMMENDED LIMITS

"AVT16" KRATIO $=2.71$

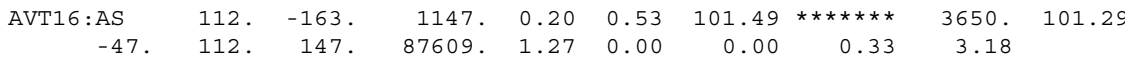

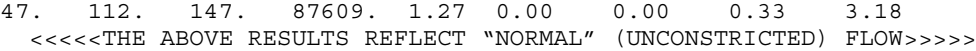

$===255$ ATTEMPTING FLOW CLASS 3 (6) SOLUTION.

$$
\text { WS } 3 \text { N, LSEL }=\quad 98.72 \quad 96.12
$$


WSPRO OUTPUT FILE (continued)

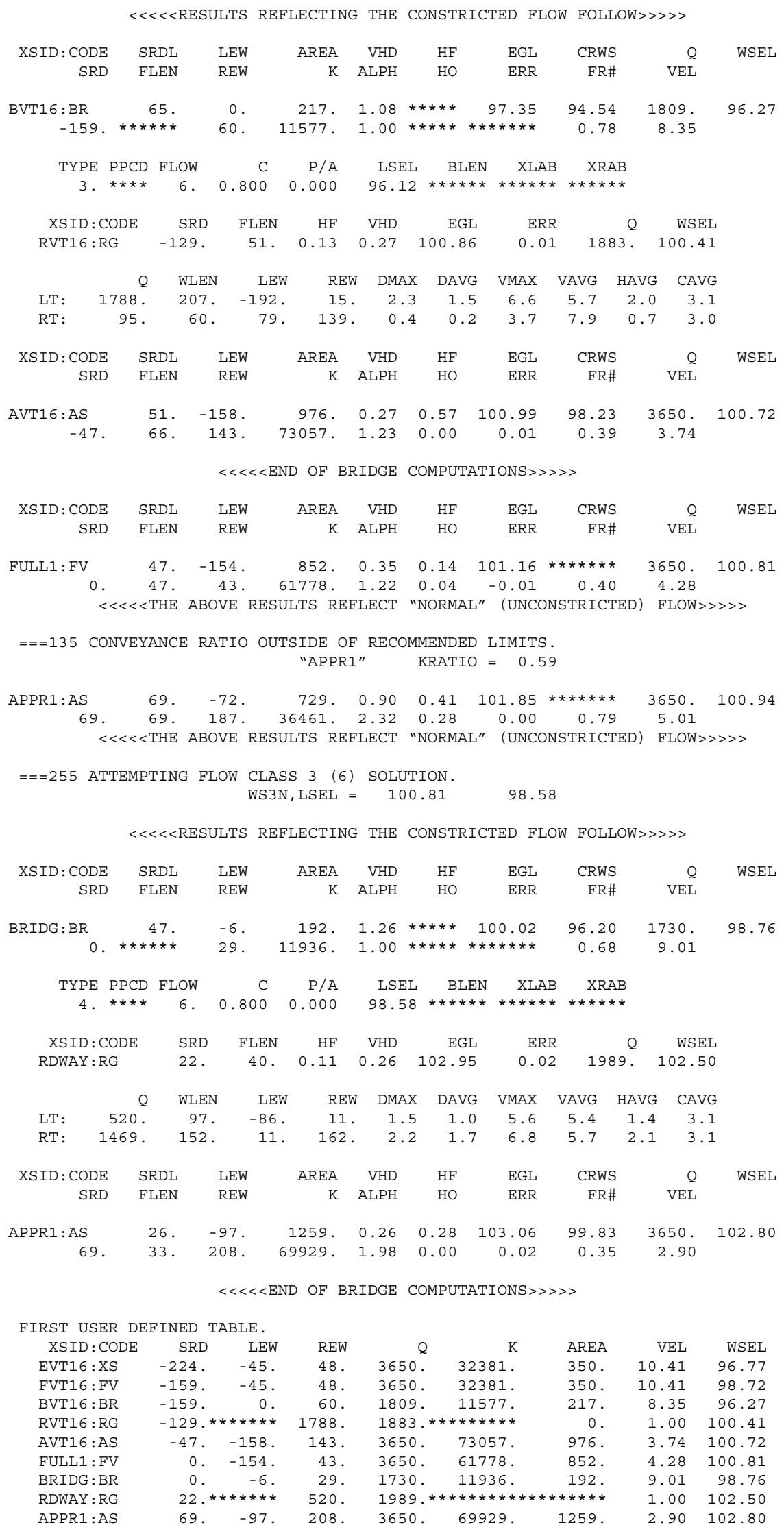


WSPRO OUTPUT FILE (continued)

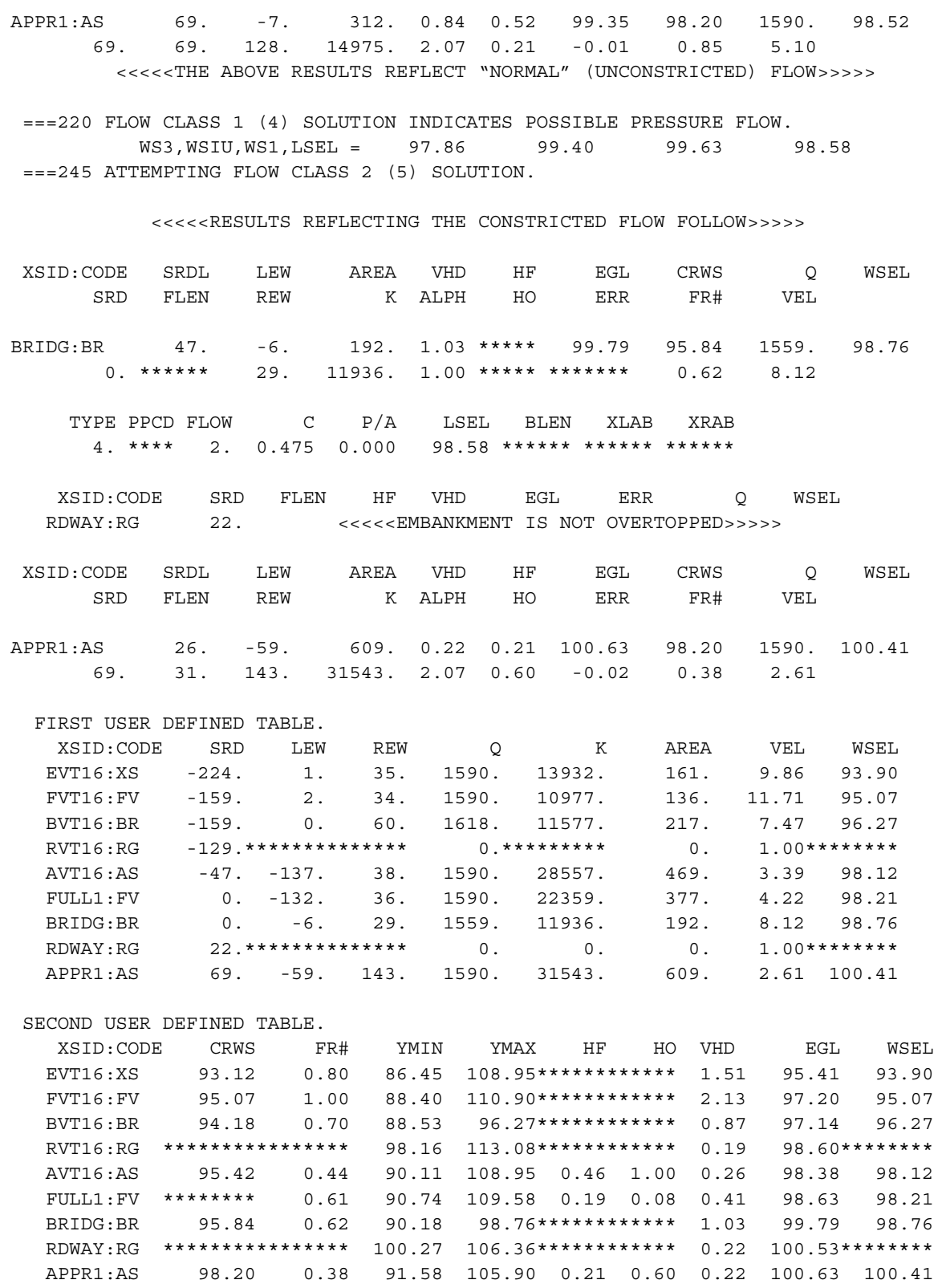




\section{APPENDIX C:}

\section{BED-MATERIAL PARTICLE-SIZE DISTRIBUTION}




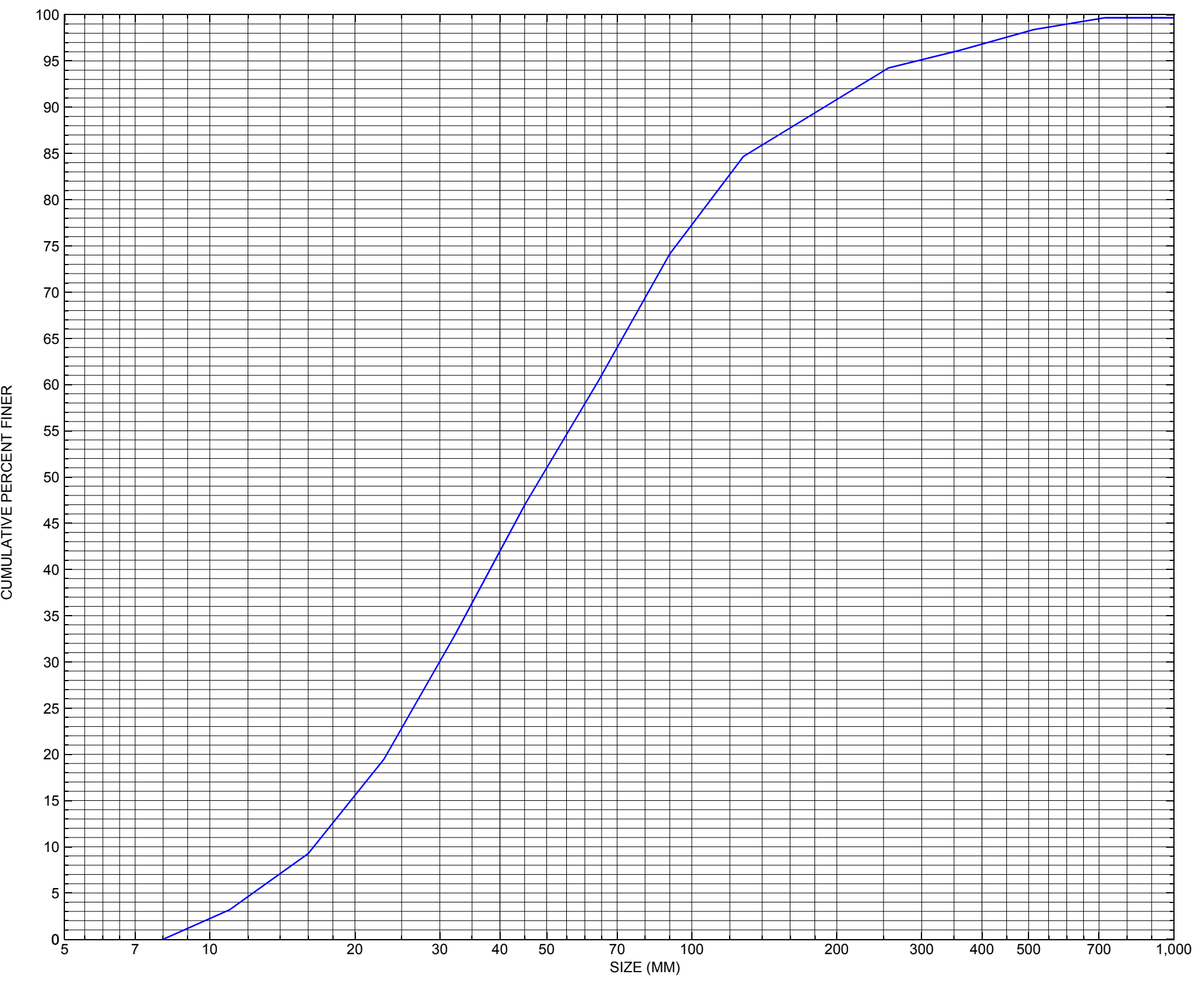

Appendix C. Bed material particle-size distribution for a pebble count in the channel approach of structure GLOVTH00030006, in Glover, Vermont. 


\section{APPENDIX D: \\ HISTORICAL DATA FORM}




\section{Structure Number GLOVTH00030006}

\section{General Location Descriptive}

Data collected by (First Initial, Full last name) M. WEBER

Date $(M M / D D / Y Y) \_\mathbf{0 8} / \underline{\mathbf{0 4}} / \underline{\mathbf{9 4}}$

Highway District Number (I - 2; nn) 09

Town (FIPS place code; I - 4; nnnnn) $\mathbf{2 8 0 7 5}$

Waterway (I - 6) BARTON RIVER

Route Number TH003

Topographic Map Crystal.Lake

Latitude (I - 16; nnnn.n) $\mathbf{4 4 4 2 4}$
County (FIPS county code; I - 3; nnn)

Mile marker (I - 11; nnn.nnn) $\mathbf{0 0 0 0 0 0}$

Road Name (I - 7): -

Vicinity (I - 9) $\mathbf{0 . 0 2}$ MI TO JCT W VT16

Hydrologic Unit Code: $\mathbf{0 1 1 1 0 0 0 0}$

Longitude (i - 17; nnnnn.n) 72112

\section{Select Federal Inventory Codes}

FHWA Structure Number (I - 8) $\mathbf{1 0 1 0 0 8 0 0 0 6 1 0 0 8}$

Maintenance responsibility $(I-21 ; n n)$

Year built (I - 27; YYYY) 1974

Average daily traffic, ADT (I - 29; nnnnnn) $\mathbf{0 0 0 2 7 0}$

Year of ADT (I - 30; YY) $\mathbf{9 1}$

Opening skew to Roadway $(I-34 ; n n) \quad 45$

Operational status $(I-41 ; X)$ A

Structure type (I- 43; nnn) $\mathbf{5 0 1}$

Approach span structure type $(I-44 ; n n n) \quad \mathbf{0 0 0}$

Number of spans (I - 45; nnn) $\mathbf{0 0 1}$

Number of approach spans (I - 46; nnnn) 0000

Comments:

Structural inspection report of 7/20/93 indicated the structure is a prestressed, precast, concrete-slab bridge. There is 2-3 feet of channel scour along the left abutment. The abutment and wingwall concrete was reportedly in good condition with no settlement cracks. The channel makes moderate to sharp bend towards bridge. A low gravel point bar along right abutment has developed. Minor embankment erosion was noted. The ambient mid-surface velocity is 3 feet per second. 


\section{Bridge Hydrologic Data}

Is there hydrologic data available? $\underline{\mathbf{Y}}$ if No, type ctrl- $n$ h VTAOT Drainage area $\left(m i^{2}\right): \underline{\mathbf{1 8 . 9}}$

Terrain character:

Stream character \& type: -

Streambed material: Boulders and stones

Discharge Data (cfs): $\quad \mathrm{Q}_{2.33}$

$\mathrm{Q}_{50} \mathbf{2 6 0 0}$

Record flood date (MM /DD/YY): - $/$ - $/$ -

$\begin{array}{ll}Q_{10} \frac{\mathbf{1 2 0 0}}{\mathbf{3 2 0 0}} & Q_{25} \stackrel{\mathbf{2 0 0 0}}{\mathrm{Q}_{100}} \mathrm{Q}_{500}-\end{array}$

Water surface elevation (ft): -

Estimated Discharge (cfs):

Velocity at $\mathrm{Q}$ $(\mathrm{ft} / \mathrm{s}):$

Ice conditions (Heavy, Moderate, Light) : Light

Debris (Heavy, Moderate, Light): Light

The stage increases to maximum highwater elevation (Rapidly, Not rapidly):

The stream response is (Flashy, Not flashy):

Describe any significant site conditions upstream or downstream that may influence the stream's stage: -

Watershed storage area (in percent):

The watershed storage area is: - _ (1-mainly at the headwaters; 2- uniformly distributed; 3-immediatly upstream oi the site)

Water Surface Elevation Estimates for Existing Structure:

\begin{tabular}{|l|l|l|l|l|l|}
\hline Peak discharge frequency & $Q_{2.33}$ & $Q_{10}$ & $Q_{25}$ & $Q_{50}$ & $Q_{100}$ \\
Water surface elevation (ft) $)$ & - & - & - & - & - \\
Velocity $(\mathrm{ft} / \mathrm{sec})$ & - & - & - & - & - \\
\hline
\end{tabular}

Long term stream bed changes: -

Is the roadway overtopped below the $\mathrm{Q}_{100}$ ? (Yes, No, Unknown): $\mathbf{U} \quad$ Frequency: -

Relief Elevation $(f t)$ :

Discharge over roadway at $Q_{100}\left(f^{3} / \mathrm{sec}\right)$ :

Are there other structures nearby? (Yes, No, Unknown): Upstream distance (miles): Town: If No or Unknown, type ctrl-n os Highway No. : Structure No. : Year Built:

Clear span (ft): Clear Height (ft): Full Waterway $\left(f t^{2}\right)$ : 
Downstream distance (miles): Town: Year Built:

Highway No. : Structure No. : Structure Type:

Clear span (ft): Clear Height $(f t)$ : Full Waterway $\left(f^{2}\right)$ : -

Comments:

\section{USGS Watershed Data}

Watershed Hydrographic Data

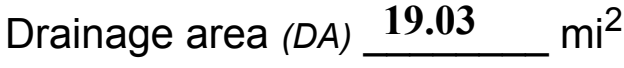
Lake/pond/swamp area 0.73 $\mathrm{mi}^{2}$

Watershed storage (ST) $\%$

Bridge site elevation 948 $\mathrm{ft}$

Headwater elevation 2277 $\mathrm{ft}$

Main channel length 7.08 $\mathrm{mi}$ $10 \%$ channel length elevation 994 $\mathrm{ft} \quad 85 \%$ channel length elevation $\mathrm{ft}$

Main channel slope $(S)$

(S) 50.01 $\mathrm{ft} / \mathrm{mi}$

Watershed Precipitation Data

Average site precipitation in Average headwater precipitation in

Maximum 2yr-24hr precipitation event $(124,2)$ in

Average seasonal snowfall (Sn) $\mathrm{ft}$ 


\section{Bridge Plan Data}

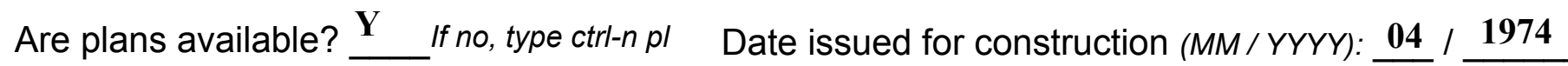
Project Number SAB - 7316 Minimum channel bed elevation: $\underline{\mathbf{4 8 9 . 0}}$ Low superstructure elevation: USLAB $\underline{497.91}$ DSLAB $\underline{\text { 497.72 }}$ USRAB $\underline{497.53}$ DSRAB $\underline{497.34}$ Benchmark location description:

$-$

Reference Point (MSL, Arbitrary, Other): Arbitrary Datum (NAD27, NAD83, Other): Arbitrary Foundation Type: 1 (1-Spreadfooting; 2-Pile; 3- Gravity; 4-Unknown)

If 1: Footing Thickness $\mathbf{2} \quad$ Footing bottom elevation: $\underline{\mathbf{4 8 6 . 3}}$

If 2: Pile Type: ___ (1-Wood; 2-Steel or metal; 3-Concrete) Approximate pile driven length: If 3: Footing bottom elevation: -

Is boring information available? $\underline{\mathbf{Y}}$ If no, type ctrl-n bi Number of borings taken: $\underline{\mathbf{2}}$

Foundation Material Type: 1 (1-regolith, 2-bedrock, 3-unknown)

Briefly describe material at foundation bottom elevation or around piles:

Silt and gravel

Comments:

The footing bottom elevation shown above is an average of that for the left abutment (486.0 feet) and the right abutment ( 486.75 feet). 


\section{Cross-sectional Data}

Is cross-sectional data available? If no, type ctrl-n xs

Source (FEMA, VTAOT, Other)? $\underline{\mathbf{Y}}$

Comments:

This cross-section is the downstream face.

\begin{tabular}{|l|l|l|l|l|l|l|l|l|l|l|l|}
\hline Station & & $\mathbf{7 . 3}$ & $\mathbf{7 . 5}$ & $\mathbf{6 . 1}$ & - & - & - & - & - & - & - \\
\hline Feature & $\mathbf{0}$ & $\mathbf{2 0}$ & $\mathbf{4 0}$ & - & - & - & - & - & - & - & - \\
\hline $\begin{array}{l}\text { Low chord } \\
\text { elevation }\end{array}$ & LAB & - & $\mathbf{R A B}$ & - & - & - & - & - & - & - & - \\
\hline $\begin{array}{l}\text { Bed } \\
\text { elevation }\end{array}$ & $\mathbf{9 3 3 . 6}$ & $\mathbf{9 3 3 . 3}$ & $\mathbf{9 3 3 . 0}$ & - & - & - & - & - & - & - & - \\
\hline $\begin{array}{l}\text { Low chord } \\
\text { to bed }\end{array}$ & $\mathbf{9 2 6 . 3}$ & $\mathbf{9 2 5 . 8}$ & $\mathbf{9 2 6 . 9}$ & - & - & - & - & - & - & - & - \\
\hline Station & - & - & - & - & - & - & - & - & - & - & - \\
\hline Feature & - & - & - & - & - & - & - & - & - & - & - \\
\hline $\begin{array}{l}\text { Low chord } \\
\text { elevation }\end{array}$ & - & - & - & - & - & - & - & - & - & - & - \\
\hline $\begin{array}{l}\text { Bed } \\
\text { elevation }\end{array}$ & - & - & - & - & - & - & - & - & - & - & - \\
\hline $\begin{array}{l}\text { Low chord } \\
\text { to bed }\end{array}$ & - & - & - & - & - & - & - & - & - & - & - \\
\hline
\end{tabular}

Source (FEMA, VTAOT, Other)?

Comments: -

\begin{tabular}{|l|l|l|l|l|l|l|l|l|l|l|l|}
\hline Station & & - & - & - & - & - & - & - & - & - & - \\
\hline Feature & - & - & - & - & - & - & - & - & - & - & - \\
\hline $\begin{array}{l}\text { Low chord } \\
\text { elevation }\end{array}$ & - & - & - & - & - & - & - & - & - & - & - \\
\hline $\begin{array}{l}\text { Bed } \\
\text { elevation }\end{array}$ & - & - & - & - & - & - & - & - & - & - & - \\
\hline $\begin{array}{l}\text { Low chord } \\
\text { to bed }\end{array}$ & - & - & - & - & - & - & - & - & - & - & - \\
\hline Station & - & - & - & - & - & - & - & - & - & - & - \\
\hline Feature & - & - & - & - & - & - & - & - & - & - & - \\
\hline $\begin{array}{l}\text { Low chord } \\
\text { elevation }\end{array}$ & - & - & - & - & - & - & - & - & - & - & - \\
\hline $\begin{array}{l}\text { Bed } \\
\text { elevation }\end{array}$ & - & - & - & - & - & - & - & - & - & - & - \\
\hline $\begin{array}{l}\text { Low chord } \\
\text { to bed }\end{array}$ & - & - & - & - & - & - & - & - & - & - & - \\
\hline
\end{tabular}




\section{APPENDIX E: \\ LEVEL I DATA FORM}


U. S. Geological Survey

Bridge Field Data Collection and Processing Form

Qa/Qc Check by: DLS Date: 2/9/95

\section{A. General Location Descriptive}

1. Data collected by (First Initial, Full last name) $\mathbf{E}$. BOEHMLER

Date $(M M / D D / Y Y)$

$10 / 25$

11994

2. Highway District Number 09

County ORLEANS (019)

Waterway (I - 6) BARTON RIVER

Route Number TH03

3. Descriptive comments:

The structure is a prestressed concrete slab type bridge. It is located about 0.02 miles from the intersection of TH03 with VT16. Two other individual assessments were conducted at this bridge site on the same date by M. Weber and R. Hammond.

\section{B. Bridge Deck Observations}

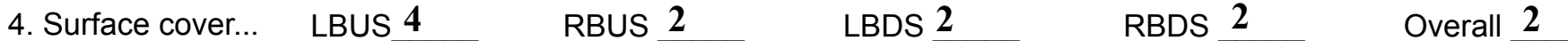

(2b us,ds,lb,rb: 1- Urban; 2- Suburban; 3- Row crops; 4- Pasture; 5- Shrub- and brushland; 6- Forest; 7- Wetland)
5. Ambient water surface...US $\underline{2}$
UB 1 DS $\underline{2}$
(1- pool; 2- riffle)

6. Bridge structure type 1 (1- single span; 2- multiple span; 3- single arch; 4- multiple arch; 5-cylindrical culvert; 6- box culvert; or 7- other)
7. Bridge length $\mathbf{4 1 . 0}$
(feet)
Span length $\underline{\mathbf{3 7 . 0}}$
(feet)
Bridge width 28.8 (feet)

\section{Road approach to bridge:}
8. LB 1 RB $\underline{0}$
( 0 even, 1- lower, 2- higher)
9. $\mathrm{LB}$ RB 1
(1-Paved, 2- Not paved)

10. Embankment slope (run / rise in feet / foot):
US left
5.8:1
US right
3.5:1

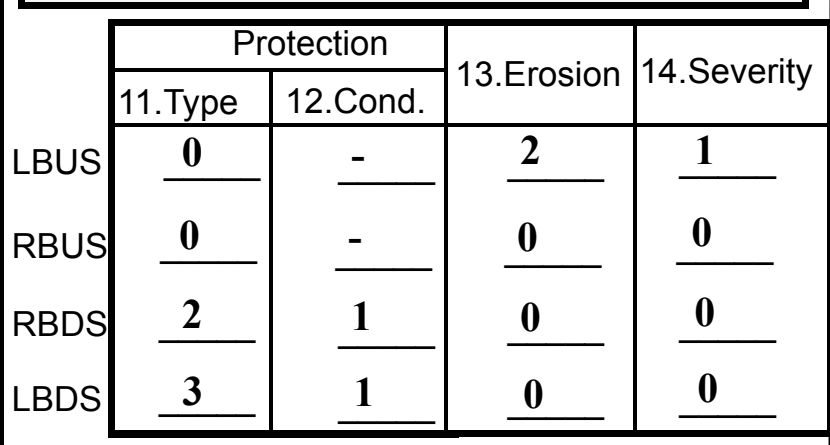

Bank protection types: 0- none; 1- < 12 inches;

2- < 36 inches; 3- < 48 inches;

4- < 60 inches; 5- wall / artificial levee

Bank protection conditions: 1- good; 2- slumped;

3- eroded; 4- failed

Erosion: 0 - none; 1- channel erosion; 2-

road wash; 3- both; 4- other

Erosion Severity: 0 - none; 1- slight; 2- moderate;
3- severe

\section{Channel approach to bridge (BF):}

15. Angle of approach: $\mathbf{1 0}$

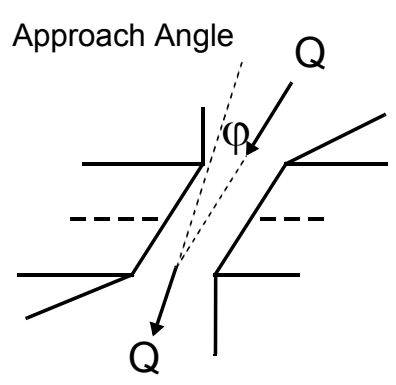

17. Channel impact zone 1 :

Where? LB $(L B, R B)$

Range? 27 feet US

Channel impact zone 2:

Where? - $\quad(L B, R B)$

Range? - $\quad$ feet (US, UB, DS) to feet -

Impact Severity: 0- none to very slight; 1- Slight; 2- Moderate; 3- Severe
16. Bridge skew: $\mathbf{3 0}$

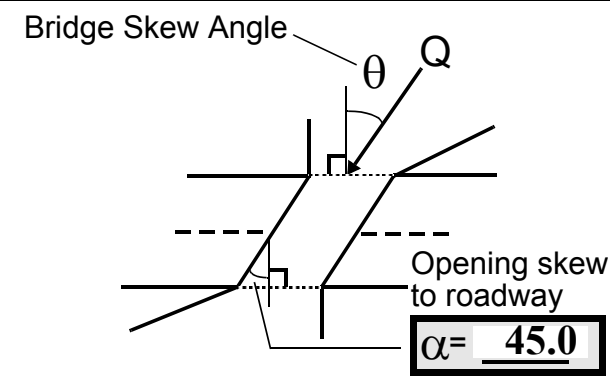

\section{Exist? $\mathbf{Y}(Y$ or $N)$}

Severity 1

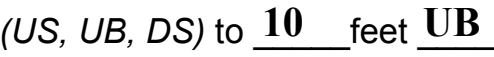

Exist? $\mathbf{N}(Y$ or $N)$

Severity -

o roadway 
18. Bridge Type: 4

1a- Vertical abutments with wingwalls

1 b- Vertical abutments without wingwalls

2- Vertical abutments and wingwalls, sloping embankment Wingwalls parallel to abut. face

3- Spill through abutments

4- Sloping embankment, vertical wingwalls and abutments

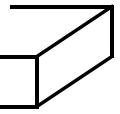

Wingwall angle less than $90^{\circ}$.
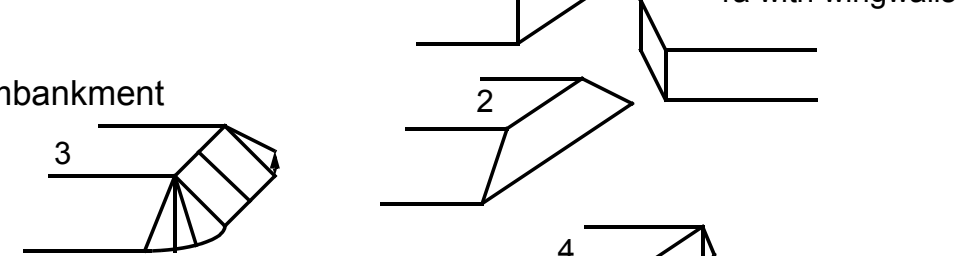

19. Bridge Deck Comments (surface cover variations, measured bridge and span lengths, bridge type variations, approach overflow width, etc.)

Measurements of bridge dimensions were the same as found on the historical form except for the roadway width measured curb to curb which was 26.0 feet.

Surface coverage on the left bank upstream is mainly a lawn with a narrow row of trees near the top of the stream bank. The right bank downstream surface cover also is a lawn with a house in close proximity to the channel (within about 30 feet) and a gravel driveway. Surface cover on the left bank downstream has a house set back only 20 feet or so from the bank with mainly a grass yard surrounding it. The right bank downstream is covered by asphalt (VT16). Stone fill protection on the left downstream road approach is protecting against erosion by a small storm drainage gully, which runs down along the embankment. The roadwash effect appears very slight on the upstream left road approach. Protection on the downstream right road approach is also protecting against erosion of the fill supporting the roadway to a bridge just downstream on Vermont State Route 16.

\section{Upstream Channel Assessment}

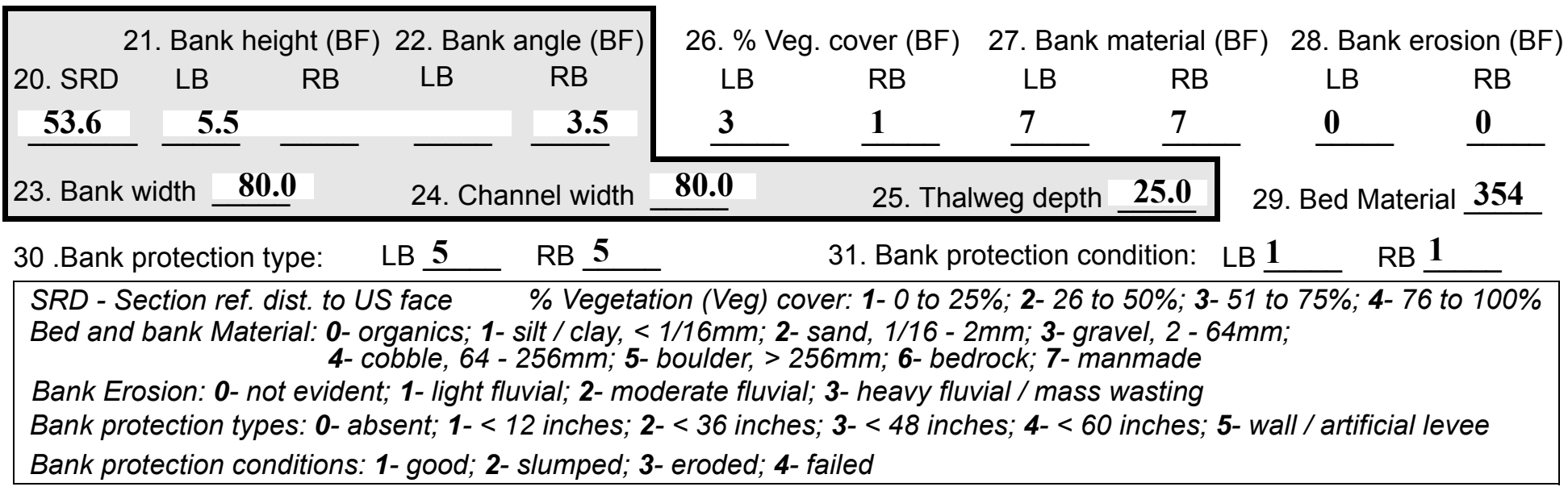

32. Comments (bank material variation, minor inflows, protection extent, etc.):

The boulder material on the bed apparently is "float" material on top of a dense clay, sand, and fine to coarse gravel material perhaps placed to protect bed against erosion. For the most part, the boulders are not interconnected with the finer material below. A field-stone dry-masonry wall extends from the upstream end of the upstream left wingwall beyond 100 feet upstream on the left bank. A predominantly cut stone slab dry-wall extends from the upstream end of the upstream right wingwall beyond 100 feet upstream. The stream overall is channelized upstream of the bridge. 
33.Point/Side bar present? $\mathbf{Y}(Y$ or N. if N type ctrl-n pb)34. Mid-bar distance: 13 35. Mid-bar width: 14

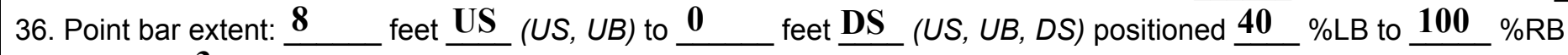

37. Material: $\mathbf{3}$

38. Point or side bar comments (Circle Point or Side; Note additional bars, material variation, status, etc.):

The mid-bar distance given is 13 feet under the bridge from the upstream face along the thalweg. The point bar ends at the downstream face of the bridge. The predominant material is a medium size gravel with a few cobbles and boulders.

39. Is a cut-bank present? $\mathbf{N}$ (Y or if $N$ type ctrl-n $c b)$ 40. Where? - $\quad$ (LB or RB)

41. Mid-bank distance: -

42. Cut bank extent: feet (US, UB) to feet (US, UB, DS)

43. Bank damage: (1- eroded and/or creep; 2- slip failure; 3- block failure)

44. Cut bank comments (eg. additional cut banks, protection condition, etc.):

NO CUT BANKS

45. Is channel scour present? $\mathbf{N}$ ( $Y$ or if $N$ type ctrl-n cs)

47. Scour dimensions: Length Width Depth : Mid-scour distance:

48. Scour comments (eg. additional scour areas, local scouring process, etc.):

NO CHANNEL SCOUR

49. Are there major confluences? $\mathbf{N}$

51. Confluence 1: Distance Confluence 2: Distance 52. Enters on Enters on 54. Confluence comments (eg. confluence name):

NO MAJOR CONFLUENCES
50. How many? -

53. Type(1- perennial; 2- ephemeral)

Type (1-perennial; 2- ephemeral) ( $L B$ or $R B)$

\section{Under Bridge Channel Assessment}

55. Channel restraint (BF)? LB 2

\begin{tabular}{|ccccc}
\hline \multicolumn{2}{|c}{ 56. Height (BF) } & \multicolumn{3}{c}{57 Angle (BF) } \\
LB & RB & LB & RB \\
$\mathbf{1 9 . 0}$ & & & $\mathbf{1 . 5}$ & \\
\hline
\end{tabular}
(1- natural bank; 2- abutment; 3- artificial levee)

58. Bank width (BF) -

59. Channel width -

61. Material (BF)

LB RB

$\underline{2} \quad 7$

Bed and bank Material: 0- organics; 1- silt / clay, < 1/16mm; 2- sand, 1/16 - 2mm; 3- gravel, 2 - 64mm; 4- cobble, 64 - 256mm; 5- boulder, > 256mm; 6- bedrock; 7- manmade

62. Erosion (BF)

LB RB

7
60. Thalweg depth $\mathbf{9 0 . 0}$
63. Bed Material -

Bank Erosion: 0- not evident; 1- light fluvial; 2- moderate fluvial; 3- heavy fluvial / mass wasting

64. Comments (bank material variation, minor inflows, protection extent, etc.):

345

While the bed material at the right bank side under the bridge is a medium gravel, the left bank side is boulder material mostly. The predominant size is in the coarse gravel and cobble range probably. 
65. Debris and Ice Is there debris accumulation?

67. Debris Potential (1- Low; 2- Moderate; 3- High)

69. Is there evidence of ice build-up? $\underline{1}(Y$ or $N)$

70. Debris and Ice Comments:

1

There is little or no constriction of the channel at the bridge due to the channelization upstream. The stream gradient is moderate. Therefore, debris is likely to be pushed through the bridge and ice is unlikely to accumulate.

\begin{tabular}{|l|c|c|c|c|c|c|c|c|}
\hline Abutments & $\begin{array}{c}\text { 71. Attack } \\
\angle \text { (BF) }\end{array}$ & $\begin{array}{c}\text { 72. Slope } \angle \\
\text { (Qmax) }\end{array}$ & $\begin{array}{c}\text { 73. Toe } \\
\text { loc. (BF) }\end{array}$ & $\begin{array}{c}\text { 74. Scour } \\
\text { Condition }\end{array}$ & $\begin{array}{c}75 . \text { Scour } \\
\text { depth }\end{array}$ & $\begin{array}{c}\text { 76. Exposure } \\
\text { depth }\end{array}$ & 77. Material & 78. Length \\
\hline LABUT & & $\mathbf{2 0}$ & $\mathbf{9 0}$ & $\mathbf{2}$ & $\mathbf{2}$ & $\mathbf{2 . 0}$ & $\mathbf{0 . 0}$ & $\mathbf{9 0 . 0}$ \\
\hline RABUT & $\mathbf{1}$ & $\mathbf{0}$ & $\mathbf{9 0}$ & & & $\mathbf{1}$ & $\mathbf{0}$ & $\mathbf{3 5 . 5}$ \\
\hline
\end{tabular}

Pushed: $L B$ or RB

Toe Location (Loc.): 0- even, 1- set back, 2- protrudes

Scour cond.: 0- not evident; 1- evident (comment); 2- footing exposed; 3-undermined footing; 4- piling exposed; 5- settled; 6- failed

Materials: 1- Concrete; 2- Stone masonry or drywall; 3- steel or metal; 4- wood

79. Abutment comments (eg. undermined penetration, unusual scour processes, debris, etc.):

$-$

1

A local scour hole has developed along the left abutment wall measuring 29 feet long, 3 feet wide, and 2 feet deep. The center of the scour hole is located 15 feet under the bridge from the upstream face and is positioned in the channel from $0 \% \mathrm{RB}$ to $10 \% \mathrm{LB}$. The upstream end of the left abutment is an impact zone where the flow attack on the wall and the erosion appears to be concentrated. The top of the left abutment footer is exposed from the upstream face of the bridge to nearly 30 feet under the bridge. While the top of the footer is exposed, the footing is countersunk relative to the surrounding streambed material by about 2 feet. The top of the footer is at the thalweg under the bridge.

80. Wingwalls:

$$
\begin{aligned}
& \text { Exist? Material? Scour Scour Exposure } \begin{array}{l}
81 . \\
\text { Angle? Length? }
\end{array} \\
& \text { Condition? depth? depth? }
\end{aligned}
$$

USLWW:

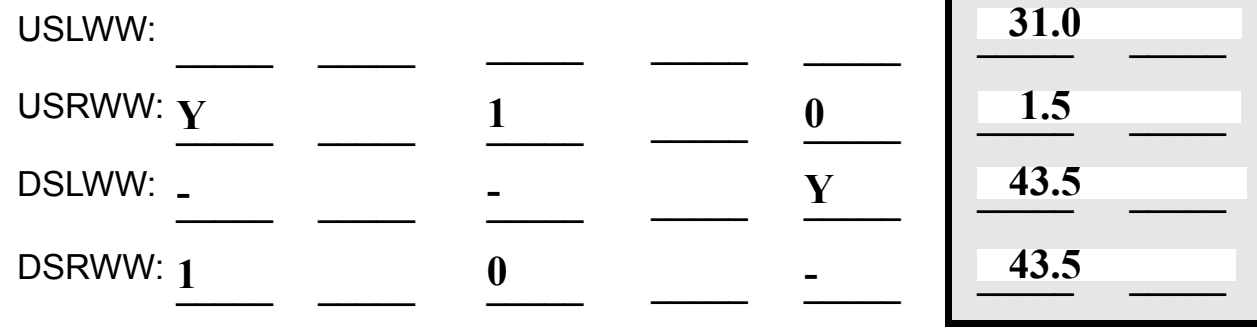

Wingwall materials: 1- Concrete; 2- Stone masonry or drywall; 3- steel or metal; 4- wood

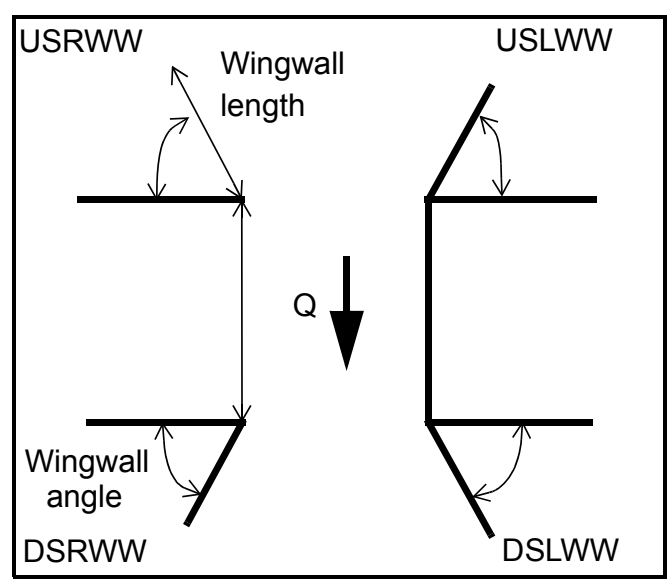

82. Bank / Bridge Protection:

\begin{tabular}{|l|l|l|l|l|l|l|l|l|}
\hline Location & USLWW & USRWW & LABUT & RABUT & LB & RB & DSLWW & DSRWW \\
\hline Type & - & $\mathbf{0}$ & $\mathbf{Y}$ & - & $\mathbf{2}$ & $\mathbf{1}$ & - & - \\
\hline Condition & $\mathbf{Y}$ & - & $\mathbf{1}$ & - & $\mathbf{1}$ & $\mathbf{1}$ & - & - \\
\hline Extent & $\mathbf{1}$ & - & $\mathbf{0}$ & $\mathbf{3}$ & $\mathbf{2}$ & $\mathbf{0}$ & $\mathbf{0}$ & - \\
\hline
\end{tabular}

Bank / Bridge protection types: 0- absent; 1- < 12 inches; 2- < 36 inches; 3- < 48 inches; 4- < 60 inches; 
83. Wingwall and protection comments (eg. undermined penetration, unusual scour processes, etc.):

-
-
-
-
-
3
1
1
3
1
1

Piers:

84. Are there piers? Sto (Y or if $N$ type ctrl-n pr)

\begin{tabular}{|l|r|r|r|r|l|l|l|}
\hline \multirow{2}{*}{$\begin{array}{l}85 . \\
\text { Pier no. }\end{array}$} & \multicolumn{3}{|c|}{ width (w) feet } & \multicolumn{5}{c|}{ elevation (e) feet } \\
\cline { 2 - 8 } & w1 & w2 & w3 & e@w1 & e@w2 & e@w3 \\
\hline Pier 1 & & & & $\mathbf{2 0 . 0}$ & $\mathbf{1 6 . 0}$ & $\mathbf{7 0 . 0}$ \\
\hline Pier 2 & $\mathbf{6 . 5}$ & $\mathbf{8 . 0}$ & & $\mathbf{7 0 . 0}$ & $\mathbf{2 0 . 0}$ & $\mathbf{1 6 . 5}$ \\
\hline Pier 3 & - & - & - & - & - & - \\
\hline Pier 4 & - & - & - & - & - & - \\
-
\end{tabular}

\begin{tabular}{|c|c|c|c|c|}
\hline Level 1 Pier Descr. & 1 & 2 & 3 & 4 \\
\hline 86. Location (BF) & ne fill & the & storm & the \\
\hline 87. Type & on & wing & drai & end \\
\hline 88. Material & the & wall & nage & of \\
\hline 89. Shape & dow & from & gully & the \\
\hline 90. Inclined? & nstre & ero- & whic & wing \\
\hline 91. Attack $\angle(\mathrm{BF})$ & am & sion & $\mathbf{h}$ & wall. \\
\hline 92. Pushed & left & by & enter & \\
\hline 93. Length (feet) & - & - & - & - \\
\hline 94. \# of piles & wing & wate & s $5 \mathbf{f t}$ & \\
\hline 95. Cross-members & wall & $\mathbf{r}$ & dow & \\
\hline 96. Scour Condition & also & flow- & nstre & \\
\hline 97. Scour depth & pro- & ing & am & \\
\hline 98. Exposure depth & tects & in $\mathbf{a}$ & from & \\
\hline
\end{tabular}

LFP, LTB, LB, MCL, MCM, MCR, RB, RTB, RFP

1- Solid pier, 2- column, 3- bent

1-Wood; 2-concrete; 3- metal; 4- stone

1- Round; 2- Square; 3- Pointed

Y-yes; $N-$ no

$L B$ or $R B$

0- none; 1- laterals; 2- diagonals; 3- both

0- not evident; 1- evident (comment);

2- footing exposed; 3- piling exposed;

4- undermined footing; 5- settled; 6- failed 
99. Pier comments (eg. undermined penetration, protection and protection extent, unusual scour processes, etc.):

$$
\begin{aligned}
& \text { N } \\
& - \\
& - \\
& -
\end{aligned}
$$

100.

\section{E. Downstream Channel Assessment}

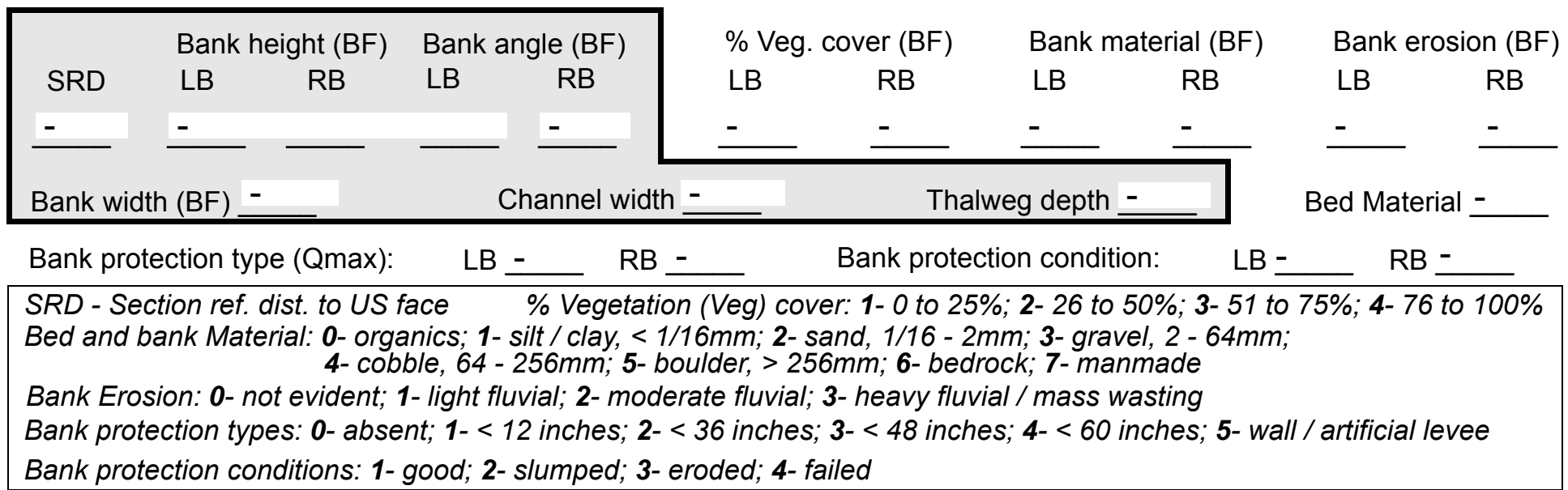

Comments (eg. bank material variation, minor inflows, protection extent, etc.):

-

\section{Is a drop structure present? __ ( $Y$ or $N$, if $N$ type ctrl-n $d s) \quad$ 102. Distance: ___ feet}

103. Drop: -_ feet 104. Structure material: ___ (1- steel sheet pile; 2- wood pile; 3- concrete; 4- other)

105. Drop structure comments (eg. downstream scour depth): 
106. Point/Side bar present? (Y or N. if N type ctrl-n pb)Mid-bar distance: -

Mid-bar width:

Point bar extent: feet -

(US, UB, DS) to feet (US, UB, DS) positioned $\%$ LB to NO $\%$ RB

Material: $\mathbf{P I}$

Point or side bar comments (Circle Point or Side; note additional bars, material variation, status, etc.):

\section{ERS}

Is a cut-bank present?

Cut bank extent: feet ( $Y$ or if $N$ type ctrl-n cb) Where? (LB or $R B)$ feet 1 (US, UB, DS)

Bank damage: 1 (US, UB, DS) to (1- eroded and/or creep; 2- slip failure; 3- block failure)

Cut bank comments (eg. additional cut banks, protection condition, etc.): 7

2

$\mathbf{0}$

$\mathbf{0}$

Is channel scour present? Scour dimensions: Length 2 Width 1 ( $Y$ or if $N$ type ctrl-n cs)

Mid-scour distance: 4

Scour comments (eg. additional scour areas, local scouring process, etc.):

ht bank material is fill with placed quarried boulders embedded in the fill. Protection on the left bank is a very poorly constructed dry wall or simply, very large stone fill. The coverage of the protection on the left bank is complete such that an estimate of the bank material is impossible. The predominant bed material downstream appears to be cobbles, which are loosely embedded in a loose medium to coarse sand and fine Are there major confluences? gr ( $Y$ or if $N$ type ctrl-n $m c)$ Confluence 1: Distance Enters on (LB or $R B)$ How many? avel.

Confluence 2: Distance Enters on (LB or $R B)$ Type (1- perennial; 2- ephemeral)

Confluence comments (eg. confluence name):

\section{F. Geomorphic Channel Assessment}

107. Stage of reach evolution

1- Constructed

2- Stable

3- Aggraded

4- Degraded

5- Laterally unstable

6- Vertically and laterally unstable 
108. Evolution comments (Channel evolution not considering bridge effects; See HEC-20, Figure 1 for geomorphic descriptors):

$\mathbf{N}$

$-$

NO DROP STRUCTURE

$\mathbf{N}$

$-$

$-$

$-$ 


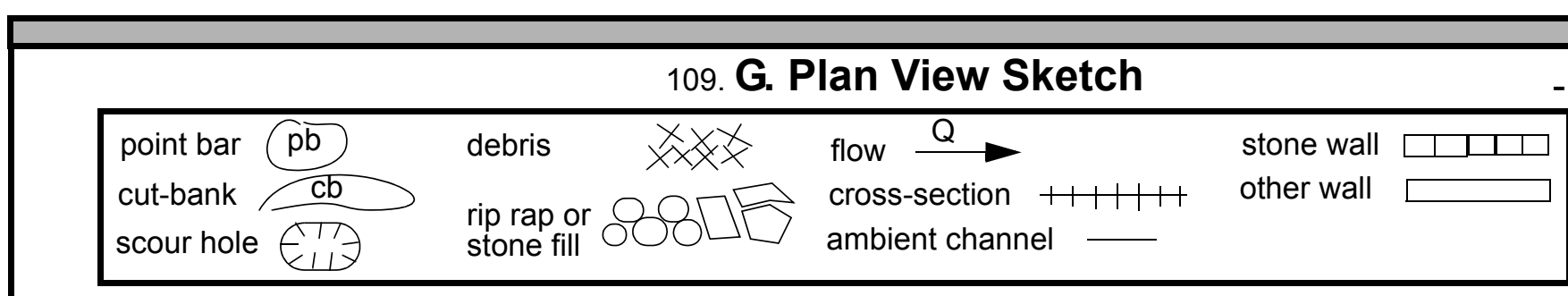


APPENDIX F:

SCOUR COMPUTATIONS 


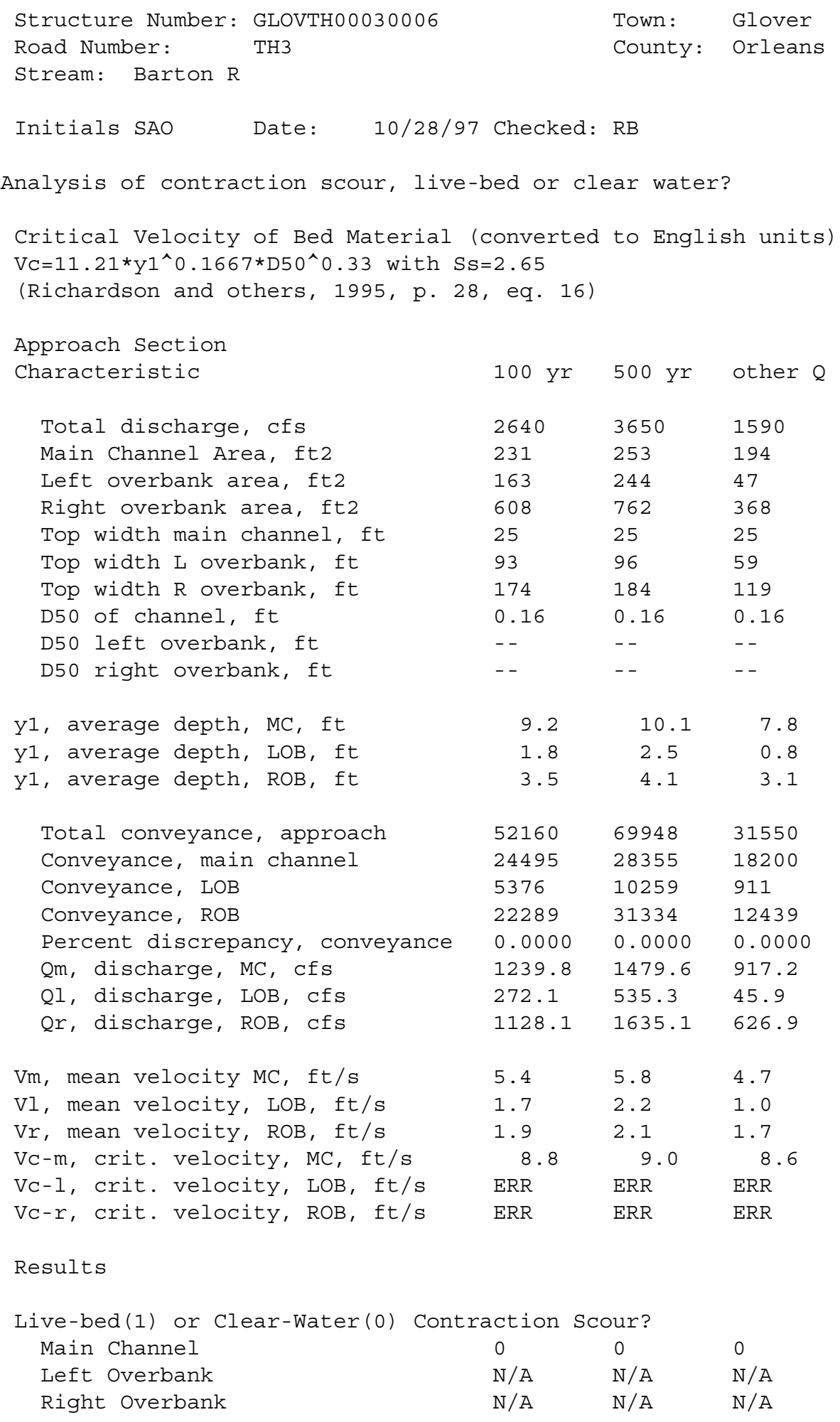


Clear water Contraction Scour in MAIN CHANNEL

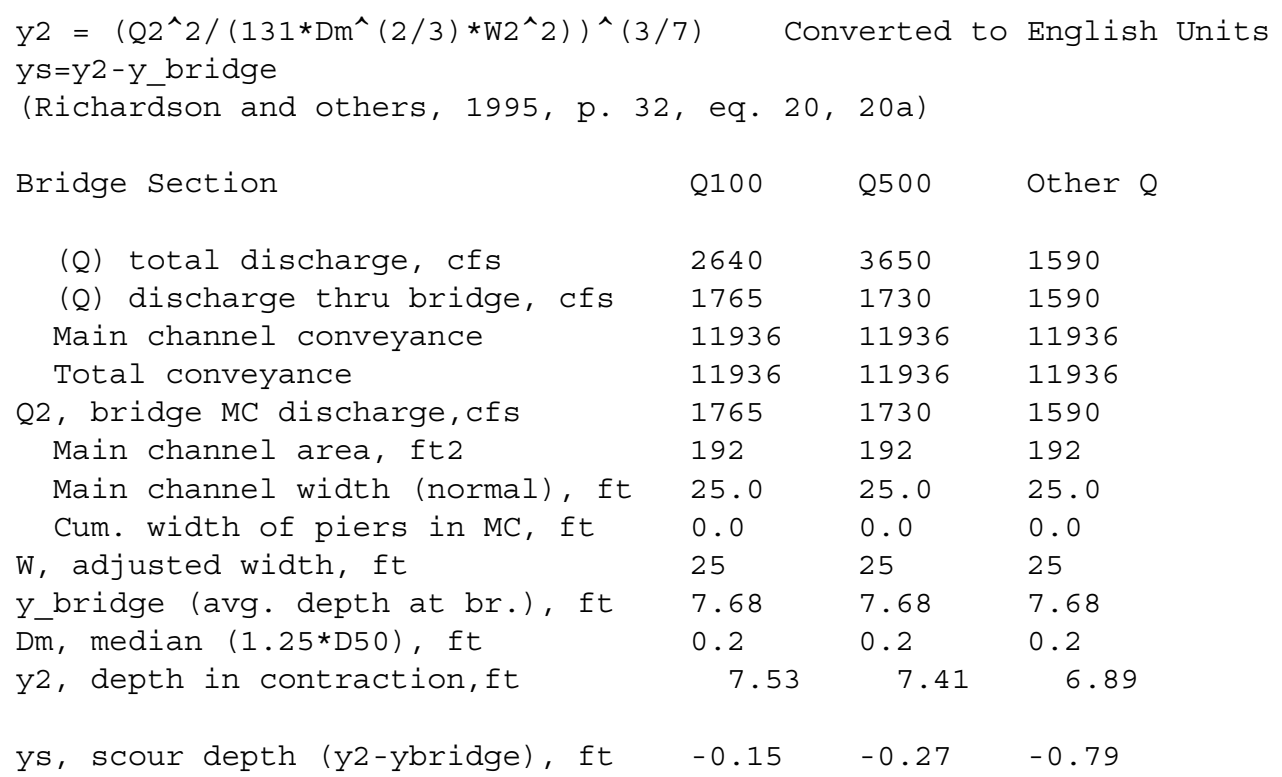

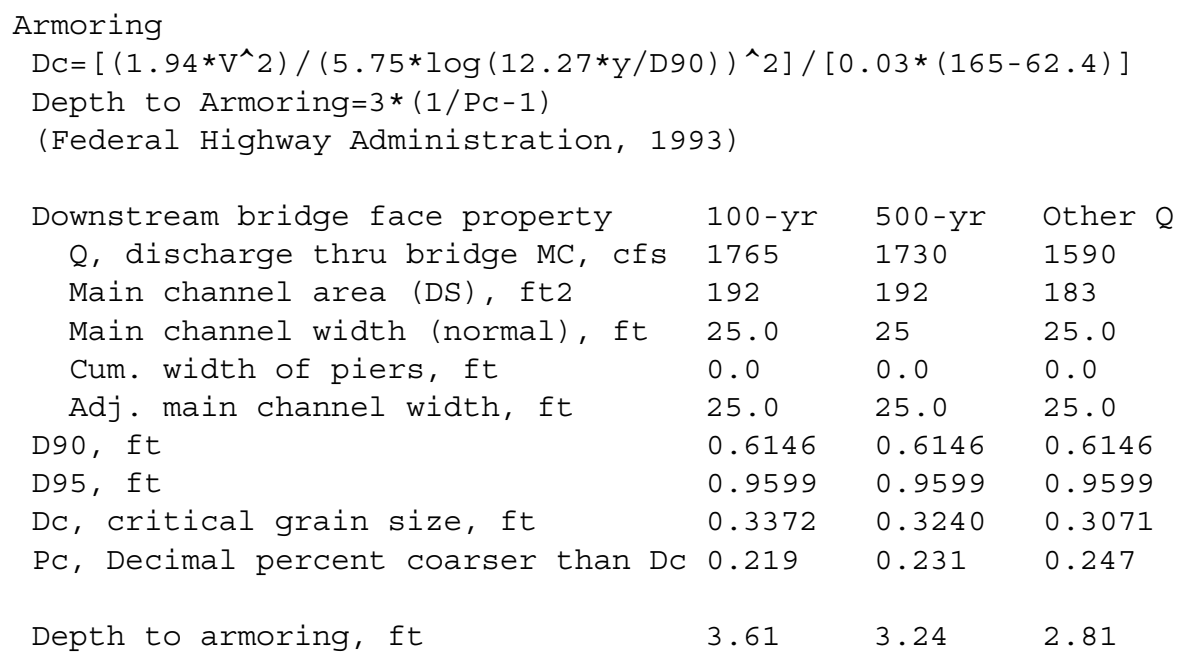




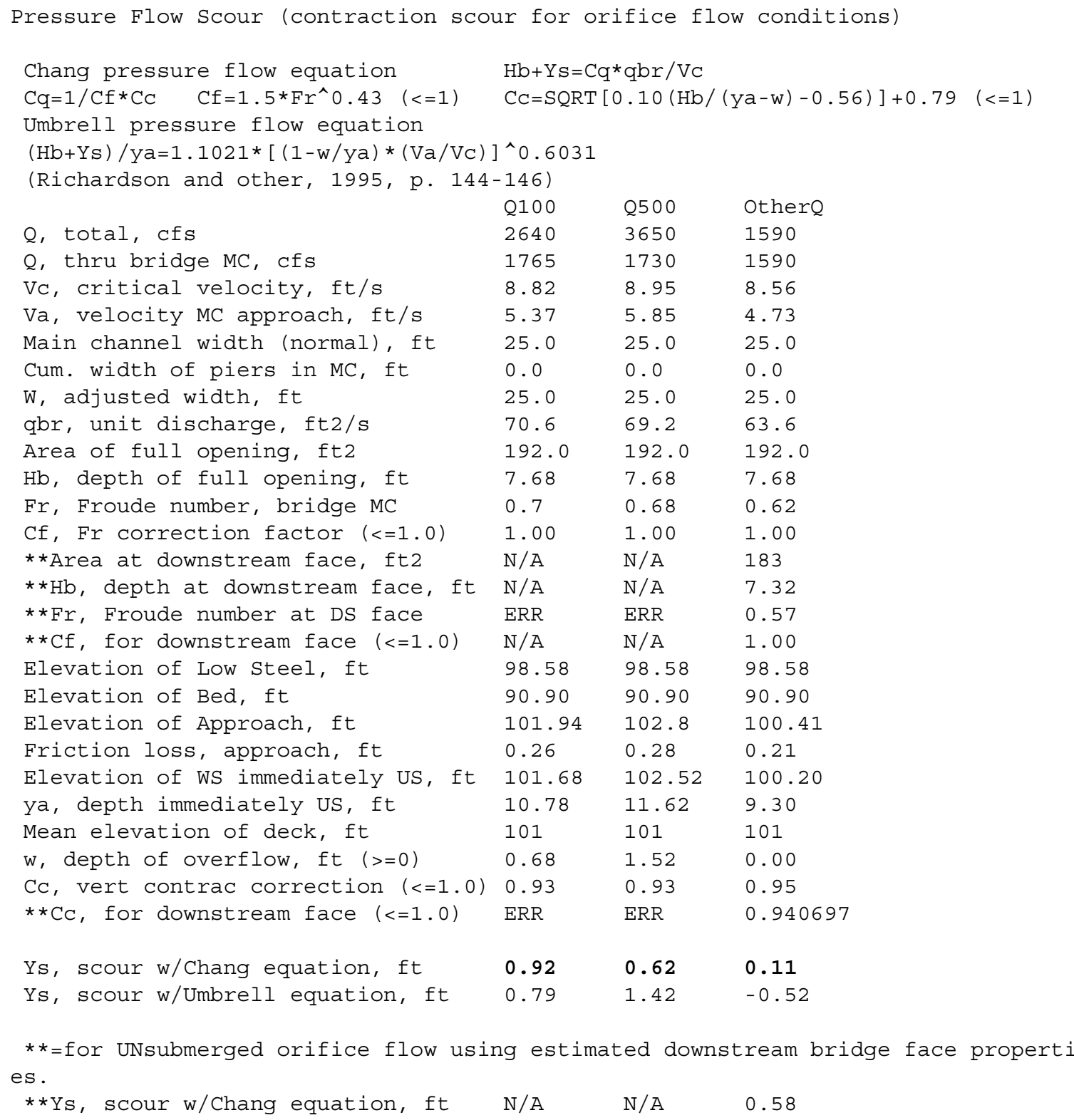




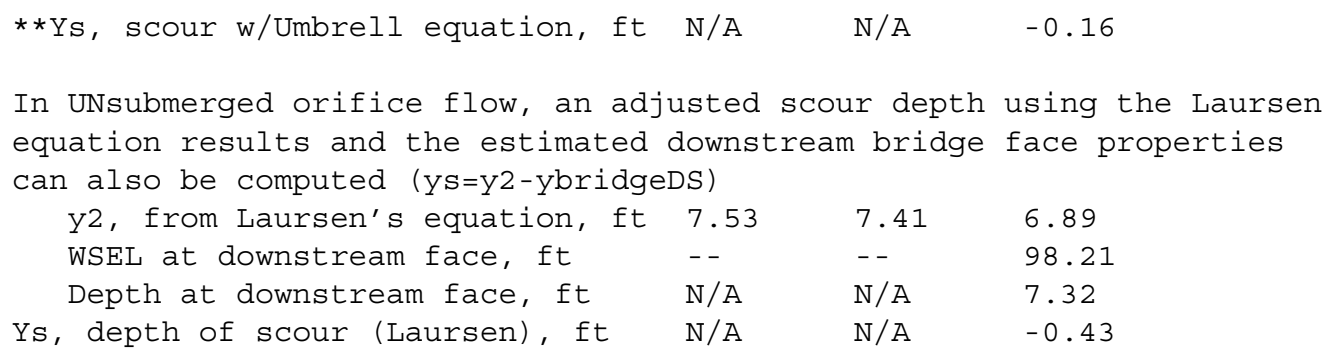

Abutment scour

Froehlich's Abutment Scour

$\mathrm{Ys} / \mathrm{Y} 1=2.27 * \mathrm{~K} 1 * \mathrm{~K} 2 *\left(\mathrm{a}^{\prime} / \mathrm{Y} 1\right)^{\wedge} 0.43 * \mathrm{Fr} 1^{\wedge} 0.61+1$

(Richardson and others, 1995, p. 48, eq. 28)

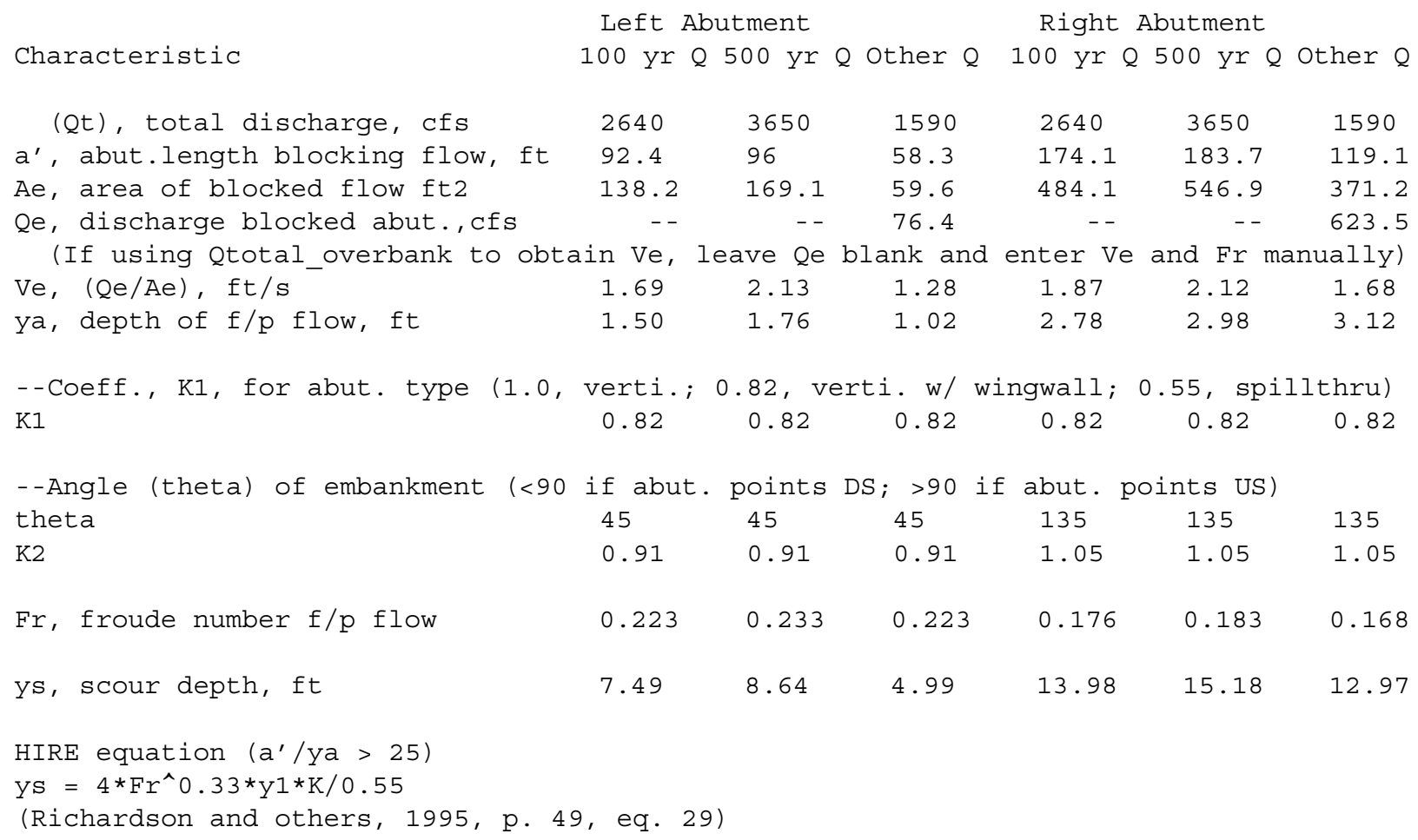




\begin{tabular}{|c|c|c|c|c|c|c|}
\hline$a^{\prime}$ (abut length blocked, ft) & 92.4 & 96 & 58.3 & 174.1 & 183.7 & 119.1 \\
\hline y1 (depth $f / p$ flow, ft) & 1.50 & 1.76 & 1.02 & 2.78 & 2.98 & 3.12 \\
\hline$a^{\prime} / y^{\prime}$ & 61.78 & 54.50 & 57.03 & 62.61 & 61.70 & 38.21 \\
\hline Skew correction (p. 49, fig. 16) & 0.80 & 0.80 & 0.80 & 1.10 & 1.10 & 1.10 \\
\hline Froude no. $f / p$ flow & 0.22 & 0.23 & 0.22 & 0.18 & 0.18 & 0.17 \\
\hline $\begin{array}{c}\text { Is w/ corr. factor } \mathrm{Kl} / 0.55 \text { : } \\
\text { vertical w/ } \mathrm{ww}^{\prime} \mathrm{s}\end{array}$ & 4.35 & 5.20 & 2.97 & 10.28 & 11.15 & 11.34 \\
\hline
\end{tabular}

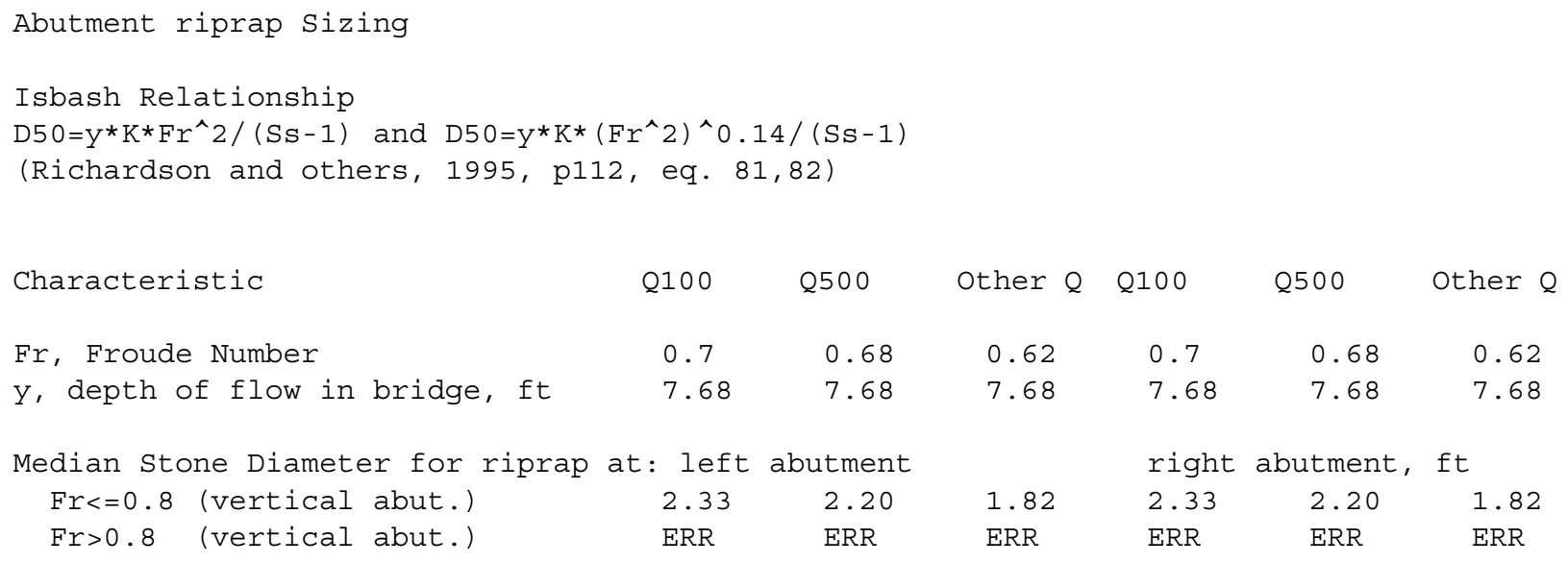


